\title{
LITERATURA HAGIOGRÁFICA LATINA EN TORNO A LOS MÁRTIRES VICENTE, SABINA Y CRISTETA DE ÁVILA (SIGLOS VII-XI)
}

\author{
POR \\ FÉLIX A. FERRER GARCíA \\ I.E.S. «Isabel de Castilla», Ávila
}

\section{RESUMEN}

En este artículo el autor recoge toda la tradición hagiográfica sobre los mártires del siglo IV Vicente, Sabina y Cristeta, tratando de estudiar la interrelación entre un discurso martirial escasamente difundido en la alta Edad Media con algunas actas y pasiones de otras figuras más consolidadas tanto en el plano cultual como en el literario. El papel de la monarquía visigoda será clave a la hora de formalizar unos textos plenamente fundamentados en unos avatares religiosos, culturales y sociales que, a medio plazo, sobre todo en los siglos XI y XII, con la eclosión de las formas culturales y artísticas románicas, expresarán la ortodoxia eclesiástica a partir de una hagiocracia inaugurada antes de la arribada islámica a la península Ibérica.

PALABRAS CLAVE: Hagiografía, Hagiocracia, Amplificación, Vulgarización, Martirio, Pasión.

\section{ABSTRACT}

In this article, the author gathers the important hagiographic tradition about ther $4^{\text {th }}$ century martyrs Vicente, Sabina and Cristeta. The study focuses on the relation between a martyrological discourse, practically unkwnown during the Middle Ages, and the records and texts about other saints and martyrs that were more influential in their cultural and literary aspects. The role of the visigotic monarchy was really important in order to establish a group of texts deeply linked to a religious, social and cultural circumstances that, specially in the $12^{\text {th }}$ and $13^{\text {th }}$ century, with the birth of the romanesque art and culture, will be the real expression of the ecclesiastic orthodoxy. This hagiocracy had been settled before the islamic arrival into the Iberian peninsula. 
KEY WORDS: Hagiographic, Hagiocracy, Popularization, Vulgarization, Martyrdom, Passion

Recibido/Received 19-07-2007

Aceptado/Accepted 12-09-2007

Hasta la invención del obispo san Segundo, en la segunda década del siglo XVI, los mártires y hermanos Vicente, Sabina y Cristeta habían sido encumbrados como patronos de Ávila, levantándose desde los años iniciales del siglo XII un sorprendente y espléndido templo románico localizado extramuros de la ciudad, la basílica dedicada a los Santos Mártires ${ }^{1}$. Sin embargo, son muy escasos los datos verídicos sobre los mártires, desconociéndose hasta hoy testimonios epigráficos y arqueológicos romanos o visigodos en la cripta de la basílica. Algunos datos más precisos desde una perspectiva documental aparecen en los himnarios de Toledo y Silos, así como en el códice Silense. También del siglo VII debe ser la Passio, mientras que de los siglos IX y X se conservan tanto la misa omnium fidelium, los sacramentarios de Toledo y Silos y el antifonario de León, recogiéndose algunos fragmentos en los calendarios mozárabes, el Virgiliano y el del obispo Recemundo de Córdoba.

Sin embargo, los mártires abulenses cuentan con escasos testimonios anteriores al siglo IX. A partir de la siguiente centuria su culto se reanima mediante pasionarios y legendarios, coincidiendo, además, con la incorporación al mundo religioso abulense (fragmentado y abandonado institucionalmente) de una nueva veneración legendaria relacionada con la imagen de la Soterraña, románica, soterrada ante el avance musulmán, poseedora a partir del siglo XII de una cripta en la basílica que, como espacio sagrado, había estado vinculada a los mártires ${ }^{2}$.

\footnotetext{
${ }^{1}$ Vid. F. A. Ferrer García, La invención de la iglesia de San Segundo. Cofrades y frailes abulenses en los siglos XVI y XVII, Ávila 2006; Rupturas y continuidades históricas: el ejemplo de la basílica de San Vicente de Ávila, siglos XII-XVII, Ávila 2007 (en prensa).

2 «Año de 893. Gouernando la romana naue Sergio II, la monarquía española de don Ramiro y la silla episcopal abulense don Pedro I, en el día 9 de septiembre, víspera de la Natividad de nuestra Señora, estando celebrando los oficios diuinos en la iglesia de San Viçente de Áuila, oyeron los clérigos muy gran estruendo en las soterrañas (que se edificaron para la firmeça del edificio y mejor planta de este templo), vajaron abajo todos y hallaron la imagen de nuestra Señora en vn nicho que oy corresponde a las espaldas de su retablo, a donde a sido y es venerada desde aquellos tiempos con el título de la Virgen de la Soterraña, por el sitio de su milagrosa inuención. (Tiene también el título de apostólica por estar reciuido en la tradición común que la trajeron los apóstoles a nuestra España, sin otros muchos indicios y conjeturas que lo acreditan». Archivo Diocesano de Ávila, Doc. núm 28, sign. 141/1, Cuaderno en que están escritas las noticias de la fundación del templo de S. Vicente de Áuila y sus grandeças y preuilegios y bullas apostólicas, Púsose en el archiuo de esta iglesia siendo cura propio de ella el Ldo. Iuan de Nájera. Año de MDCXXXIII. Memorias, preuilegios y bulas de la santa iglesia de San Viçente de Áuila. Sacados año de 1676,..., año de 1676, fol. 1. Códice de 71 fols, num., $220 \times 315 \mathrm{~mm}$.
}

Hispania Sacra, LX

121, enero-junio 2008, 9-46, ISSN: 0018-215-X 
El martirologio romano celebra la festividad de los tres hermanos el 27 de octubre, coincidiendo con la vigilia de los apóstoles Simón y Judas, mencionándose que a Ávila llegaron los santos Vicente, Sabina y Cristeta, los cuales, por orden del presidente Daciano, fueron tan bárbaramente estirados en el potro que les desencajaron todas las junturas de los miembros; después, poniendo sus cabezas sobre unas piedras, se las magullaron con mazos hasta hacerles saltar los sesos, con que consumaron el martirio ${ }^{3}$.

27 October. Sexto kalendas novembris. Luna. Vigilia sanctorum apostolorum Simonis et Judae. Abulae in Hispania passio sanctorum Vincentii, Sabinae et Christetae, qui primum in equuleo adeo sunt extenti, ut omnes membrorum compages laxarentur; deinde capita eorum lapidibus superposita, usque ad excussionem cerebri validis vectibus sunt contusa, atque ita martyrum compleverunt, agente praeside Daciano.

\section{Recopilación de Fuente latinas en la Alta Edad Media}

Las noticias acerca de Vicente, Sabina y Cristeta son sumamente parcas y fragmentadas. Fábrega Grau ${ }^{4}$ indica que, si no fuera por un himno (Huc vos gratifice, plebs pia convocat...) recogido por el canónigo Ulysse Chevalier en el n. ${ }^{\circ} 8.130$, que evoca una fecha anterior a la invasión musulmana, su culto habría que trasladarlo al siglo IX. Este himno es una secuencia recogida en el códice $n^{\circ} 30.845$ del British Museum de Londres, un texto en letra visigótica procedente de la abadía de Silos que se encontraba inscrito, parece ser, en un libro de Officia et Missae de rito mozárabe escrito en el siglo X y utilizado como antifonario, sin lecturas, antes de la supresión del rito hispánico a finales del siglo XI. En efecto, Chevalier recoge en su obra el himno procedente del brevia-

\footnotetext{
${ }^{3}$ Martyrologium Romanum. Gregorii XIII, editio VI Taurinensis, Taurini 1911. Hasta el año 1591 se celebró la festividad de los mártires el 27 de octubre, luego el 30 de agosto para que pudiese ser conmemorada con octava y al margen de otras fiestas (santos Simón y Judas), coincidiendo con la de otros mártires anteriores al Edicto de Constantino (Félix y Adaucto) y, curiosamente, con algunos mártires del monasterio de San Pedro de Arlanza, como Pelayo, Arsenio y Silvano, monjes sacrificados por los sarracenos a mediados del siglo X. "Y en dicho día se zelebró su fiesta, año de 1285 , y se continuó hasta el año 1591, que con autoridad pontifizial se transfirió dicha celebridad a los treinta de agosto de cada año; entre las causas que huvo, la principal fue el celebrarles con octaua sin impedimento de otras fiestas. Viene el cauildo la uíspera; y el día hazen la fiesta en procesión de tiempo ymmemorial». Archivo Parroquial de San Vicente, Ávila, Resumen y noticias avreviadas de la fundación y grandezas de este ynsigne templo de San Vizente de Áuila, conforme a noticias y papeles de sus archiuos. Hizose este cuaderno siendo cura desta yglesia el licenciado Juan de Nájera, año de 1683. Doc. sin catalogar. Pap., sin enc., 10 fols. sin num., algunos muy deteriorados.
}

4 Á. FÁBrega Grau, Pasionario hispánico. I Estudio, Madrid-Barcelona 1953, pp. 165-167. 
rio gótico-mozárabe 5 . En 1788, había insertado este mismo texto en su manuscrito sobre los obispos de Ávila el beneficiado de San Vicente José Tello Martínez (Parágrafo 21), con algunos errores del propio copista: conforte por consorte y olapibus por dapibus. El himno es el siguiente: Huc vos gratifice, plebs pia convocat / virtutum Dominus, testum atria, / consorte dapibus, vota calentia / coelorum locet in intima. / Juncti martyribus, jugiter gaudia / Vincentii teneat, munera vox pia: / Sabina recinat coelina litera, / Christetes bona dethera. / Hic mundi misera, lucra per ardico / spermunt hominum, vaffra dolentia, / cedunt punicea colla per omnia, / Rex Christe, tibi laureantia / simplix ac trinitas, te Deus, unitas. / Rogamus, precitus hurum et audias, / que ipsi petimus. Corda calentia, / inmense bone prorroga. / Sit trina deitas ac tibi gloria, / qui unus retinens, omnia judicas, / large continua perpetim secula, / sed ultra bene prosperans. Amen. / V. Letanini in Domino...

Pueblo piadoso, hacia aquí, hacia los atrios de los testigos, os convoca de forma gratificante el Señor de las virtudes, para que coparticipando en los festines sagrados, eleve vuestros votos ardientes hasta lo más profundo del cielo.

Que la voz mantenga siempre como dones piadosos los gozos de Vicente agregado a los mártires:

Resuene la canción de Sabina con su letra celestial

y con ella la de la buena Cristeta.

Ahora desprecian las miserias del mundo, ganancias inútiles, las dolorosas maquinaciones ceden el paso

a través de sus cuellos tronchados en sangre color de rosa enteramente roja, Rey nuestro, Cristo, para Ti los laureles, para Tí, Dios simple y trino, la unidad.

Rogamos que ante las preces de éstos escuches también lo que nosotros te pedimos. Prorroga el ardor de nuestros corazones

Tú que eres inmensamente bueno.

Y sea la gloria para Tí, Trina Deidad,

${ }^{5}$ U. CheValier, Repertorium Himnologicum. Catalogue des chants, hymnes, proses, séquences, tropes en usage dans l'Église latine depuis les origines jusqu'a nos jours, Lovaina 1897.

Hispania Sacra, LX

121, enero-junio 2008, 9-46, ISSN: 0018-215-X 
que, reteniéndolo todo, todo lo juzgas,

a lo largo de los siglos en continuidad perpetua,

pero logrando que el resultado sea favorable más allá de todo bien.

Amén.

V. Alegraos en el Señor...6

La historia de los tres hermanos aparece recogida en el siglo X en un Pasionario que servirá para la introducción de los mártires en la liturgia hispánica. La Passio sanctorum martyrum Vincentii, Sabinae et Christetae, qui passi sunt in urbs Abula sub Datiano praeside; die V kalendas, novembres. Deo gratias, se recoge en el manuscrito de Cardeña del Bristish Museum, Add. 25.600, recopilada luego en la Bibliotheca Hagiographica Latina, Bruselas, 1898-1911 y por Fábrega en el Pasionario hispánico ${ }^{7}$. El manuscrito fue redactado a mediados del siglo X (954-966) a partir de cincuenta y cinco pasiones de mártires correspondientes a cincuenta y tres festividades celebradas en la liturgia mozárabe, además de las fiestas de Santiago el Mayor y de los santos Pedro y Pablo. Los mártires de Ávila se celebran el 28 de octubre, mientras que el martirologio romano -como se ha visto- traslada la fecha al día anterior. En el folio ' 250 b' de dicho manuscrito procedente de San Pedro de Cardeña se lee la noticia sobre los mártires abulenses:

Passio sanctorum martyrum Vincentii, Sabine et Christete qui passin sunt in urbe Abela sub Datiano preside; die V klds. Nobembres. Deo gratias.

In illis diebus dum post corporem Salvatoris adventum et pro redemtione nostra...

Expl.....et omnis infirmitas amovetur per eum qui sanctos suos coronavit per bonam confessionem.

Cui est honor et gloria, virtus et potestas in saecula saeculorum. Amen.

Otra fuente sobre los santos de Ávila procede del manuscrito de Santo Domingo de Silos, un códice escrito probablemente en el año 992, que pasó de un monasterio dedicado a san Pelagio al burgalés de Silos y, finalmente, a la Biblioteca Nacional de París (Nouvelles Acquisitions Latines, 2180). Este manuscrito, destinado inicialmente para el rezo del oficio divino, se encuentra mutilado en el folio ' 255 d', después de haber presentado las pasiones de santa Cecilia, los santos Julián y Basilisa, Inés y Emerenciana, Teodosia y Félix de Nola, cuando se lee la pasión de los santos Servando y Germano de Medina Si-

\footnotetext{
6 Traducción del catedrático e intérprete jurado de Latín Dr. Francisco Ruiz de Pablos (Universidad Católica de Ávila. IES «Isabel de Castilla», Ávila).

7 Pasionario Hispánico (siglos VII-XI). II Textos, ed. Á. FÁBrega Grau, Madrid-Barcelona 1955, pp. 358-363; Pasionario Hispánico, ed. P. Riesco Chueca, Sevilla 1995, pp. 214-225.
} 
donia, suponiéndose que los folios arrancados contendrían las pasiones de Vicente, Sabina y Cristeta, la traslación de san Saturnino y, con cierta seguridad, la de los Innumerables de Zaragoza. El presbítero Fábrega indica, además, que la Passio íntegra de los abulenses se arrancó del códice tal vez para añadirla, con otras, a otro pasionario o legendario compuesto en un tiempo posterior a la entrada del nuevo santoral romano en la liturgia española a fines del siglo XI, una vez arrinconados los libros de la liturgia hispánica (mozárabe) después de la supresión de la misma por obra de Gregorio VII.

Ambos documentos, el de Cardeña y el de Silos, son sobre todo santorales más o menos completos acerca de la irrupción de mártires y santos que se produce en los períodos visigodo y mozárabe. En algunos casos, la amplitud de los textos permite sospechar que los copistas amplificaron algunos sucesos, exageraron algunos diálogos y trastocaron ciertos contenidos, razones que permiten suponer la existencia de un Pasionario previo más sencillo y libre de algunos retoques literarios 8 . Las actas transmitidas en los manuscritos de Londres y París proceden, pues, de las primitivas narraciones de los pasionarios o leccionarios visigóticos o mozárabes, creadas probablemente por autores eclesiásticos del siglo VII y difundidas luego por la literatura mozárabe, incorporando en algunos casos sucesos legendarios característicos de la alta Edad Media.

Otro manuscrito con breves referencias a los mártires de Ávila es el códice 6 de la Biblioteca Nacional de Madrid (Manuscritos Visigodos, ms. 13.016) ${ }^{9}$, con el título de Vitae sanctorum et alia, con letra minúscula visigótica de siete copistas diferentes, en que se relacionan las pasiones y vidas de Félix, Justo y Pastor, Teodosia, Torcuato y compañeros (incluyendo a san Segundo), la historia de la invención de la Santa Cruz, las vidas de Servando y Germano, Vicente, Sabina y Cristeta (Passio Vincentii, Sabine et Christeys: In diebus illis, dum post , 106), el traslado del cuerpo de san Saturnino, una lección sobre san Miguel Arcángel y las pasiones de Máximo, Julio y Marcelo.

Asimismo hay referencias muy estrictas en algunos calendarios hispáni$\cos ^{10}$. En el 'Calendario de Ripoll' (ms. 59, Archivo de la Corona de Aragón), con letra minúscula franca del siglo $\mathrm{X}$, en el mes de octubre, día 28 , se menciona a san Vicente y sus hermanas, precedido el encabezamiento del mes con

${ }^{8}$ P. QuENTIN, Les martirologes historiques du Moyen Âge. Études sur la formation de martirologe romain, París 1908, p. 148. J. VIVES, «Tradición y leyenda en la hagiografía hispánica», Hispania Sacra, 17 (1964) 495-508.

9 R. FernÁndez Pousa, «Los manuscritos visigóticos de la Biblioteca Nacional», Verdad y Vida, 10 (1945) 376-423.

10 J. Vives y Á. FÁBREGA, «Calendarios hispánicos anteriores al siglo XII», en Hispania Sacra, 2 (1949) 119-146; «Calendarios hispánicos anteriores al siglo XIII», en Hispania Sacra, 2 (1949) 339380. D. Mansilla, «Dos códices visigóticos de la Catedral de Burgos», en Hispania Sacra, 2 (1949) 381-418.

Hispania Sacra, LX

121, enero-junio 2008, 9-46, ISSN: 0018-215-X 
unas alusiones a los signos del zodiaco y algunas recomendaciones sanitarias: Octubris. Aequat et octimber sementis te $(m)$ pore Libram. In hoc mense porros plurimos quomodo uoleris manduca, et racemos utere et mustum libere, q(uia) sanitatem et solutionem faciunt.

En los calendarios mozárabes del siglo X, conservados en la biblioteca del monasterio de El Escorial, se reproduce nuevamente la festividad de los mártires abulenses. En el 'Códice Vigiliano' (ms. d. I. 2), redactado en el año 976, se sigue manteniendo la celebración hispánica del 28 de octubre (28. V. Sci. uice(n)ti et sabine), al igual que en el 'Calendario Emilianense' (ms. I. 1, redactado en el año 984): Sci. uicenti et sabine. En ambos textos se reproducen los mártires celebrados habitualmente por la liturgia hispánica anterior al siglo XI, pero surgen algunas novedades interesantes en cuanto a la duplicación de algunos santos relacionados con san Vicente de Zaragoza o con el mártir abulense. Además de la festividad destinada a san Vicente levita ( 22 de enero), se crea en estos códices, para el día 1 de septiembre, la fiesta de san Vicente y san Leto (Sci. uincenti et leti), supuestos mártires de origen africano hispanizados en el mundo mozárabe, considerados hermanos gemelos nacidos en Toledo. En este sentido, la duplicación de mártires a partir de un modelo original será una constante en la hagiografía medieval, al igual que el intento, también mozárabe, por inundar de hagiotopónimos relacionados con el martirologio y los calendarios aquellos lugares del norte de la península en los que se hacía necesario adjudicar un santo a cualquier núcleo de población o a los antiguos espacios cultuales paganos.

Otros datos aparecen en el 'Calendario primero de Silos' (S4) de finales del siglo X: Klds. Octubres D(ies) XXXI. 28 V. Scor(um) uincenti sabine et xpete; en el 'Calendario segundo de Silos' (S3), copiado en 1052 e inserto en el Liber Ordinum: Octr. M(ensis) D(ies) XXXI. 28. V. Scor(um) uincenti sabine et xpete; en el 'Calendario de Compostela' (C6), redactado en 1055: Octbr. M(ensis) $D$ (ies) XXXI. 28. V. Scor(um) uincenti sabine et xpetis i(n) abula; y, por último, en el 'Calendario silense segundo de París' (P2), escrito en el año 1072: Octbrs. M. D(ies) XXXI. V. Scor(um) uincenti sabine et xpete. $m r(u m)$. Xpi. También en el 'Calendario de León', un antifonario conservado en su archivo catedralicio, procedente de la primera mitad del siglo $X$, aparece una nueva referencia a los mártires abulenses: Octubre M(ensis) D(ies) XXXI. 28 V. Scorum uincenti sabine et xpetis i(n) abula. En este mismo antifonario de la catedral de León se registra el oficio dedicado a los santos abulenses, tratándose de una obra completa que recoge la tradición hagiográfica de los siglos VI y VII (fundamentalmente de la época del rey Wamba), incluye el repertorio musical con las antífonas cantadas en las fiestas del ciclo litúrgico y de los santos ya reconocidos hacia el año 1069, fecha de su redacción retocada, según el ritual visigóticomozárabe de España. En su recorrido textual se ofrecen los oficios de los santos 
Acisclo, Eulalia, Fructuoso, Vicente de Zaragoza, Eulalia de Barcelona, Torcuato y el resto de Varones Apostólicos, Justa y Rufina, Cucufate, Justo y Pastor y, asimismo, Vicente, Sabina y Cristeta de Ávila ${ }^{11}$.

En comparación con otros mártires del ciclo de Diocleciano, los abulenses sobresalen por la parquedad documental. Incluso en épocas tardías (finales del siglo XII), las referencias a Vicente y sus hermanas siguen siendo sumamente escuetas. Por ejemplo, en el manuscrito 815 de la Biblioteca de Montserrat, un sacramentario aragonés que incluye un calendario, se cita la festividad de los mártires en su fecha hispánica (28 de octubre): X. Octobris. 28 V. Symonis et Iudae. Vincentii, Sabinae et Christetae. No aparece en este calendario la misa propia a ellos dedicada, deduciéndose que los mártires abulenses participaban de las misas comunes de los santos: Plurimorum martyrum. Deus qui nos concedis sanctorum martyrum... Scr. Munera tibi domine nostrae deuotionis... Praesta nobis domine quaesumus intercedentibus... (fol. 105) ${ }^{12}$.

Ausentes los hermanos de otros documentos (Oracional visigótico, Codicis Veronensis, Códice Add. 30.852 del Bristish Museum, o los martirologios anteriores al siglo IX como el Jerominiano, el de Beda el Venerable o el de Lyon), la oficialización de su culto parece ser tardía a no ser por las sucintas referencias que sobre Vicente, Sabina y Cristeta se localizan en una Passio de communi del período visigótico. Ahora bien, en el terreno de las probabilidades que constantemente se mencionan en los estudios hagiográficos, se pueden destacar algunas consideraciones. En primer lugar, al himno Huc vos gratifice... se le adjudica una cronología anterior a la invasión musulmana, previa al siglo VIII, sin que existan elementos constatables para dicha etapa histórica a no ser la ausencia de cualquier referencia directa o indirecta a la llegada del islam. Únicamente cierta incorporación masiva de algunos himnos admitidos por la ortodoxia eclesiástica en el siglo VII. Pero, por otra parte, fue en este siglo cuando los concilios toledanos intentaron la supresión aquellos himnos que se recitaban en las liturgias por proceder, en algunos casos, de algunas contaminaciones priscilianistas. En segundo lugar, aunque gran parte de los historiadores reconocen la existencia de una Passio de communi en el período visigodo (siglo VI), también se puede retrasar su redacción inicial hasta las décadas finales del siglo VII y comienzos del siguiente ${ }^{13}$. En este proceso, ineludiblemente se tendrían que retardar algunas pasiones específicas, como la de santa Leocadia de Toledo y, se-

\footnotetext{
11 «Officium in diem sanctorum Vincenti, Savine et Cristetis», en Antifonario visigótico mozárabe de la Catedral de León, ed. facsímil, Madrid-Barcelona-León 1953, fol. 240 vº

12 Á. Olivar, «El Sacramentario aragonés ms. 815 de la Biblioteca de Montserrat», en Bulletin Hispanique, 28 (1926) 85; El Sacramentario de Vich, Madrid-Barcelona 1953.

${ }_{13}$ B. de GAIFFIER, «Sub Daciano praeside. Études sur quelques Pasions espagnoles», en Analecta Bollandiana, 72 (1954) 378.
}

Hispania Sacra, LX

121, enero-junio 2008, 9-46, ISSN: 0018-215-X 
guramente, la de los hermanos de Ávila. En cualquier caso, parece que ciertas noticias legendarias en torno a Vicente, Sabina y Cristeta eran ya conocidas tibiamente a finales del siglo VII, fundamentalmente en Toledo, donde se elabora la pasión de Leocadia y acaso la de los mártires abulenses, y en el Bierzo, donde Valerio y otros escritores utilizan las pasiones de Vicente y hermanas, Justa y Rufina, Félix de Gerona y Leocadia.

A pesar del respaldo monárquico de los visigodos y de la insistencia del clero toledano por articular coherentemente una narración legendaria, los abulenses no dejan de salir del anonimato, mientras que otros mártires ven cómo sus oficios se establecen de manera más precisa especialmente desde el año 675 cuando se acentúa el culto de las reliquias tras algunas disposiciones del Concilio Bracarense. En el mundo mozárabe, por otra parte, afloran algunos oficios con himnos a diversos santos (Saturnino, Clemente y los cuarenta mártires), mientras que otros contaban con algunos himnos vespertinos sin misa propia, como sería el caso de los de Ávila.

Con oficio y fiesta propia se encontraban otros dentro del ciclo litúrgico de las principales celebraciones (Natividad, Circuncisión, Epifanía, Pascua, Ascensión y Pentecostés, etc.), conteniendo con oficio propio a Torcuato con sus compañeros obispos, D. Vincentius hispanus (Vicente de Zaragoza), santas Justa y Rufina, Cosme y Damián, Fausto, Jenaro y Marcial, Servando, Germano y Romano, la virgen niña Eulalia, Leocadia de Toledo y otros mártires. Otro grupo de santos tenía misa con oración común (Justo y Pastor, Acisclo, Emeterio y Celedonio, Eulalia de Barcelona, etc.), incluyendo asimismo a los tres hermanos: Kalendarii Mozarabici hodierni semestre alterum. Octobris. Aureus numerus XIX. Kldas. VI. Vincentii \& Sabine \& Christete NM. VI capparum. Vigilia. En definitiva ${ }^{14}$, no hay misa, oración, oficio específico sobre Vicente y sus hermanas, deduciéndose que se mantendrían en la liturgia mozárabe unas orationes et preces comunes para todos los santos mártires, omnes sancti martyres. Siglos después, el cardenal Francisco Jiménez de Cisneros, en Roblesii Hispanicum Latinum, en la página 269, señalará que algunos santos y mártires tienen un oficio particular, mientras que otros mantienen himnos vespertinos (hymnos vespertinarum), como D. Vincentius, Sabina \& Christeta.

Así pues, aunque con una narración más tardía que otros modelos santos, la hagiografía de los mártires abulenses parece compartir, dentro de ciertas limitaciones, las características de las dos tradiciones hagiográficas de la liturgia hispánica. Por

${ }^{14}$ Liturgia antiqua hispanica, gotica, isidoriana, mozarabica, toletana, mixta, illustrata. Cum additionibus, Scholiis, \& variantibus lectionibus. Tomus primus, Romae MDCCXLVI, fol. LXXXVII. Liturgia mozarabica. Tratactus historico-chronologicus de Liturgia antiqua hispanica, gotica, isidoriana, mozarabica, toletana, mixta..., collegit, digessit et illustravit Joannes Pinius, Romae MDCCXL, fol. LXXVII. 
una parte, la llamada tradición A o «de los manuscritos», es decir, libros que en mayor o menor medida concuerdan con los textos del Oracional de Verona, incluyendo también los manuscritos de centros litúrgicos procedentes del norte de la Península y de la parroquia toledana de Santa Leocadia. Gran parte de los códices y anotaciones sobre Vicente y las hermanas derivan precisamente de una incorporación tardía a esta rama de la liturgia. Por otro lado, la creación tardía de una narración estrictamente original sobre los mártires abulenses se reflejaría en la actuación del clero toledano en el último cuarto del siglo VII. Se inicia así una tímida incorporación de la Passio a la liturgia desde la iglesia de las Santas Justa y Rufina. Esta tradición B pasaría más tarde al misal y breviario hispánicos codificados y publicados por orden del cardenal Cisneros en los años 1500 y 1502, respectivamente.

M. Férotin, en el Liber Mozarabicus Sacramentorum ${ }^{15}$, concede a los hermanos Vicente, Sabina y Cristeta el carisma de mártires, celebrándose su fiesta el 28 de octubre, siendo Ávila su cuna y su culto el VII, surgiendo las primeras misas como piezas litúrgicas a finales del siglo VIII, cuando todo el pueblo cristiano -dice la oración Missa en los santos abulenses- gózase en la victoria de la Trinidad de éstos y de éstos por la Trinidad, Vicentium inquam, cum Sabina et Christeta sororibus, quórum fides pervenit ad fructum. Si bien en los calendarios mozárabes la festividad se celebra el día 28 de octubre, al igual que el martirologio histórico de Floro (In urbe Abula... 28 oct.), otras fuentes la trasladan al 27 del mismo mes, pasándose más tarde en la diócesis de Ávila al 30 de agosto o al día siguiente, según diversos calendarios, con carácter «solemne» en la ciudad y como «memoria obligatoria» en el resto de la diócesis. Otros martirologios medievales insisten en el día 27 de octubre, como los de Adón (Abela civitate), Usuardo (Abula) y Wandeberto (Hinc sextum mártir pugnans Vincentius ornat, Chrystetae hoc pariter Sabinaque virgo triumphat).

Además se celebra la festividad de los mártires en Talavera de la Reina, diócesis de Toledo, como «memoria obligatoria», y en la diócesis de Burgos. En esta última se celebraría la festividad de los santos Vicente, Sabina y Cristeta desde finales del siglo XI, tras el supuesto traslado de reliquias por el rey Fernando I al monasterio benedictino de San Pedro de Arlanza, coincidiendo con la vigila de los apóstoles Simón y Judas, VI kalendas novembris, leyéndose en la missa tras la supresión de la liturgia mozárabe, algunos versículos de la carta de san Pablo a los hebreos (Hb. 2, 33-37) y otros del evangelio de san Mateo, Videns turba Jesús (Mt. 5, 1-10), alternando probablemente en Ávila con la lectura de algún fragmento de la Passio referida a los mártires, sustituyendo en

15 M. FÉrotin, Le Liber Mozarabicus Sacramentorum, Paris (Monumenta Ecclesiae Liturgica 8) 1912, LXXXIV. J. CAMARERo CuÑADO, La figura del santo en la liturgia hispánica, Salamanca-Madrid 1982, pp. 68 y 158. C. GODOY FERNÁNDEZ, «Arquitectura cristiana y liturgia: reflexión en torno a la interpretación funcional de los espacios», en Espacio, Tiempo y Forma, 2 (1989) 385

Hispania Sacra, LX

121, enero-junio 2008, 9-46, ISSN: 0018-215-X 
parte a la tradicional homilía, al igual que la lectura del Nuevo Testamento había suplantado la del Antiguo desde el siglo XI.

Esta tradición se mantendrá prácticamente hasta el Concilio Vaticano II, perseverando la lectura de la epístola de san Pablo y sustituyendo la lectura de los versículos de Mateo por otros de san Lucas, especificándose una misa de los mártires con numerosas partes cantadas, un Introito (Salus autem), el Kyrie fons bonitatis, el Gloria y la oración Collecta, seguida por una epístola cantada por el subdiácono, el Alleluia (Alleluia, laetabitur iustus), el evangelio cantado por el diácono, el ofertorio y la oración Secreta cantada por el sacerdote, al igual que el Prefacio, siguiendo la misa con el canto gregoriano del Sanctus, el Pater Noster, la oración Agnus Dei, la Comunión (Qui mihi ministrat), concluyendo el oficio con la oración Postcommunio y el Ite Missa est cantado por el diácono y coro.

Coincidiendo con los resultados litúrgicos y festivos del Concilio de Trento, desde el año 1591 y con autoridad pontificia, se trasladó la fiesta al 30 de agosto, aunque en el apartado del Breviarium Romanum dedicado a la Officia propria sanctorum quae in Hispania ex concessione apostolica recitantur, se celebra el 31 del mismo mes, como escribió Tello Martínez, con una oración a los principales patronos de la ciudad, indicándose que el joven Vicente nació en Évora (Heborae in Portugallia natus) bajo la presidencia de Daciano, leyéndose en el oficio las lecciones IV, V y VI, añadiéndose, por otra parte, que fuera del episcopado abulense se conmemora a san Raimundo Nonato (Lectio IX). Sin embargo, el oficio recogido por el beneficiado de la basílica del siglo XVIII insiste en el origen talaverano de los hermanos: Abulae in Hispania vectoniae sanctorum Vincentii, Sabinae et Christetae, eius sororum qui ex Ebora Carpetanorum oriundi. Con anterioridad al concilio tridentino se oficiaba en la basílica el rezo propio procedente del breviario gótico-mozárabe, de la Iglesia de Toledo, con numerosas interpolaciones procedentes de la Passio redactada en la época visigoda e incorporada definitivamente a la liturgia unos siglos más tarde, siempre antes de la repoblación del rey Alfonso VI, mencionándose algunos fragmentos comunes para los mártires y las referencias concretas a Daciano, los tormentos, la serpiente y la cueva ${ }^{16}$.

\section{Die XXVII octobris}

In festo sanctorum Vincentii, Sabinae et Christetae,

Fratrum martyrum

Ad vesperas

Antiphona. Laureati sanguine proprio gloriosi Christi athlete Vincentius, Sabina et Christeta in conspectu Dei epulantur. (Psalmi de Communi plurimorum martyrum).

${ }^{16}$ J. Tello Martínez, Cathálogo sagrado de los obispos... de Ávila (1788), ed. F. A. Ferrer García, Ávila 2001, pp. 91-124. 
Aña [Alia]. Beatus Vincentius dixit: Obmutesce diabole et noli exprobare quem colere debueras, si demens non essus.

$\underline{\text { Añ }\lceil\text { Alia]. Dominum Deum tuum adora et illi soli servire propera. }}$

Aña 「Alia]. Invicta jubenis etas tiranorum persecitione accusata Jesum Christum alacri animo confietur.

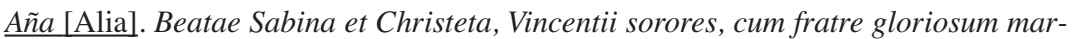
tirum compleverunt.

Capitulum

Justorum anime, etc.

Hymnus ex breviario gótico-mozarábico...

Ad magnificat. Aña [Alia]

Martyrum Christi solemnia veneranda celebramus, qui martirii certamine lauream in choro angelorum felici gaudio gloriantur, ut eorum pio interventu sufilti, gaudere cum illis et nos sine fine valeamus.

$\underline{\text { Oratio }}$

Omnipotens sempiterne Deus, qui in sanctorum martyrum tuorum Vincentii, Sabine et Christete, cordibus flammam tue dilectionis accendisti da mentibus nostris fidei, spei et charitatis augmentum, ut quórum gaudemus triunphis, proficiamus exemplis. Per Dominum nostrum verum Christum, etc.

In secundis vesperis

Antiphona. Inhumata milites corpora relinquentes et ne sepelirentut comminantes, ad Datianum suam letitiam nuntiare reprediuntur.

Aña \Alia]. Et licet mandada canibus corpora reliquissent, et nec ipsa miseratu cristiana, que provenisse sibi mártires gaudebat, audebat ea custodire.

Aña [Alia]. Unde credo nec vana nobis fides et ideo humanum nullum ex cubiis vigilasse obsequium, nec honori martyrum divina custodia deesse crederetur.

Aña [Alia]. Subito nutu Dei ex cabernis terre serpentina egressa bellua, cepit Christi martires mortuos custodire.

Aña \Alia]. O quam laudabilis es Christi in tuorum defensione martyrum, quia quos viventes eligis, nec mortua eorum corpora derelinquis.

\section{Ad magnificat. Aña \Alia】}

Letermur hodie dien festum sanctorum martyrum voce jaccunda celebrando, in quórum victoria angelorum chorus inefabili exultat letitia, animas qui eorum susciprentes cantando deferunt ad coeli sublimia, ubi cum Christi felices regnant in gloria.

Reliqua sumantur de communi plurimorum martyrum.

Desde fines del siglo XVI, el oficio de los mártires abulenses constaba de un Introitus en el que se leía parte de un salmo (Ps. 36: Salus autem justorum...), una oración con la epístola de san Pablo (Hb. 2, 33), otro fragmento del salmo 33, una pieza del evangelio de la misa precedente, incluyéndose además los precisos rituales en el offertorium, communio y postcommunio.

Hispania Sacra, LX

121, enero-junio 2008, 9-46, ISSN: 0018-215-X 
Offertorium (Sap. 3). Justorum animae in manu Dei sunt, et non tanget illos tormentum malitiae: visi sunt oculis insipientium mori, illi autem sunt in pace. Aleluya.

Communio. Posuertunt mortalia servorunt tuorum Domine, escas volatilius coeli, carnes sanctorum tuorum bestiis terrae: secundum magnitudinem brachii tui posside filios morte punitorum.

Postcommunio. Haec nos communio, Domine, purget a crimine: et intercedentibus sanctis martyribus tuis Vincentio, Sabina et Christeta, coelestis remedii faciat esse consortes. Per Dominum...

Tan escasas noticias acerca de los mártires y santos de la Antigüedad en la diócesis abulense provocaron una curiosa propuesta del doctor Juan de Montemayor en una sesión del cabildo catedralicio, celebrada el 4 de febrero de 160217. Insistió el canónigo en comprar un breviario de mano de la Iglesia de Ávila, «en el qual está el rezo de nuestros sanctos y mártires... que por aora no ay noticia dellos». La compra se haría a un padre de la Compañía de Jesús, que sabía que cierta persona poseía ese breviario y que podía ser adquirido, como así fue, por 200 ducados.

Asentado el culto de los mártires en la ciudad y diócesis de Ávila, a partir del siglo XII y dentro de la nueva liturgia romana, las noticias a partir del Pasionario y de los calendarios mozárabes serán asimiladas y divulgadas en la ciudad por medios visuales, el cenotafio, y por mecanismos orales y escritos, festivos y litúrgicos Unas veces de manera fragmentaria, otras con cierta extensión, las informaciones sobre Vicente, Sabina y Cristeta surgen en privilegios, bulas papales y documentos internos de la parroquia. Paralelamente, la basílica y sus santos, cada vez más variados, serán una referencia en las obras de Gonzalo de Ayora, Antonio de Cianca, Juan de Marieta en su obra «Del martirio de san Vicente de Ávila y sus hermanas Sabina y Cristeta» ${ }^{18}$, Luis Pacheco de Espinosa, Luis Ariz, Gil González Dávila, Pablo Verdugo de la Cueva, Luis Vázquez de Santa Teresa ${ }^{19}$, Juan Tamayo Salazar ${ }^{20}$, Bartolomé Fernández Valencia, Juan de Nájera, Enrique Flórez y José Tello Martínez, añadiendo los documentos de manos anónimas de la época moderna hasta el siglo XVIII'21.

${ }^{17}$ Archivo Catedralicio de Ávila. Actas capitulares. Libro 34 (1602-1603), fol. $12 \mathrm{v}$.

18 J. de MARIETA, Historia eclesiástica y flores de santos de España, I, Cuenca, 1954.

${ }^{19}$ L. VÁzqueZ de SANTA Teresa, Defenssorio de estar en Ávila los santos cuerpos de nuestros patrones, y no en otra parte, ms. original conservado en Archivo Privado.

${ }^{20}$ Anamnesis siue commemorationis sanctorum hispanorum: pontificum, martyrum, confessorum, virginum, viduarum ac sanctarum mulierum... / auctore D. Ioanne Tamayo Salazar..., tomus sextus et ultimus, Lugduni 1659.

${ }^{21}$ Véanse otras referencias a las obras de estos autores en mi edición del Cathálogo sagrado...., pp. 14-15. 
CONVERGENCIAS LITERARIAS, DIVERGENCIAS MARTIRIALES. LA ECLOSIÓN DE LOS MÁRTIRES HISPANOS ${ }^{22}$

Como en otras narraciones, la Passio de los mártires Vicente, Sabina y Cristeta oscila entre lo impuesto y lo creado, entre la leyenda, surgida en un medio históricamente determinado, y la narración que sufre, dentro de un ámbito tradicionalmente cristiano, cambios de posición estético-religiosa en el tiempo, de generación en generación, en un mismo modelo cultural, y diferencias interpretativas de acuerdo con la tradición cultural de unos conjuntos concretos, clero, nobleza, ciudadanos, campesinos y grupos marginales. Así pues, el relato hagiográfico supone una variabilidad del discurso tradicional y una apertura hacia nuevas fuentes, acontecimientos e influencias, sin contar con las deformaciones lingüísticas y semánticas que lleva en sí cualquier narración inscrita en un mundo de características eminentemente ágrafas ${ }^{23}$.

${ }^{22}$ Fuentes hagiográficas sobre los Santos Vicente, Sabina y Cristeta anteriores al Concilio de Burgos (a. 1080):

Passio de communi... (ca. 580-610)

Passio sancti Vincenti, Sabinae et Christetae (ca.685-710; redacción inicial derivada de la Passio de communi.

Martirologios del siglo IX (Floro, Adón, Usuardo y Wandeberto)

Calendario de León. A.C. León (ca.901-950; texto primario)

Códice núm. 30.645. Bristish Museum. Londres (s. X, Silos; incluye el himno Huc vos gratifice...) Códide de Cardeña, Add. 25.600. British Museum. Londres (ca.954-966; incluye en el 'fol. 250 b'

Passio sanctorum Vincentii, Sabinae et Christetae)

Calendario de Ripoll. A.C. Aragón (s. X). Barcelona

Calendario Virgiliano. Biblioteca de El Escorial (ca.976)

Calendario Emilianense. Biblioteca de El Escorial (ca.984)

Códice núm. 6 (ms. 13.016). Biblioteca Nacional. Madrid

Calendario Primero de Silos (S 4) (ca. 990-995)

Códice de Silos núm. 2.180. Bibliothèque National. París (ca. 992; en el desaparecido 'fol. 255 d' se encontraba la Passio de los mártires abulenses, pasando a algún pasionario posterior al año 1080)

Passio sanctorum martyrum Vincentii, Sabinae et Christetae... (fin. s. X; redacción definitiva, pasó a la liturgia general hispánica)

Calendario Segundo de Silos (S 3). A. C. Burgos (ca. 1052; Liber Ordinum)

Calendario de Compostela (C 6). A.C. Santiago de Compostela (ca. 1055)

Antifonario de la Catedral de León. A.C. León (ca. 1069; redacción definitiva; incluye el Officiu in diem sanctorum Vincenti, Savine et Cristetis)

Calendario Segundo Silense de París (P 2). Bibliothèque National. París (ca. 1072)

${ }^{23}$ Hay que anotar, a título de ejemplo, un par de cuestiones relacionadas con las lenguas: la proliferación de santos, o su duplicación, a partir de un nombre (Vicente, Víctor) que es adoptado y adaptado en medios históricos variados, y, por otra parte, la creación casi automática de nuevos santos por medio de erróneas lecturas de manuscritos (las «Once Mil Vírgenes»; un fragmento de fémur de una de ellas se conservaba en la cripta de la basílica de San Vicente), documentos epigráficos o defectuosa audición y entendimiento de algunos vocablos latinos en un momento en que la lengua de Roma empieza a establecerse como «lengua muerta», es decir, ajena, esotérica, incomprensible para los feligreses de la ple-

Hispania Sacra, LX

121, enero-junio 2008, 9-46, ISSN: 0018-215-X 
Más tarde, la irrupción de un elaborado relato hagiológico, extendido y oficializado desde los tiempos repobladores de Alfonso VI, procede indudablemente de los medios cercanos a una cultura oficial y eclesiástica. Como narración, la de los mártires abulenses obedece a una determinación compleja, a una consideración socio-ideológica en la que habría que considerar la caracterización textual antes que un campo retórico, los procedimientos de la forma discursiva, oral y escrita, que vienen a ser los resortes de la manipulación consciente, los elementos destinados a oscurecer las condiciones históricas de los mártires. Son unos efectos aparentemente involuntarios en un proceso que acarrea el establecimiento litúrgico de los elegidos.

Los primeros mártires documentados de la Hispania romana son Fructuoso, obispo de Tarragona, y los diáconos Augurio y Eulogio, bajo el imperio de Valeriano. Este, que tras un primer edicto del año 257 prohibiendo el culto cristiano y las reuniones en los cementerios, ordena la ejecución de los clérigos que no ofrezcan sacrificios a los dioses y la confiscación de los bienes de los cristianos pertenecientes a los grupos sociales elevados. Unas décadas antes son perseguidos bajo Decio, e incluso con emperadores anteriores, Facundo y Primitivo en Galicia, Marcelo y Nona, con sus tres hijos, en León, Acisclo y Victoria en Córdoba y san Fermín, obispo de Pamplona, martirizado en Amiens o Toulouse. Con Decio, Emeterio y Celedonio en Calahorra, santa Marta en Astorga y las santas Justa y Rufina en Sevilla. Sin embargo, ninguno de estos casos está documentado a finales del Imperio, estando su culto más relacionado con la época visigoda, reconociéndose que los que han escrito la historia de los primeros tiempos, dirá Zacarías García Villada, «han creído llenar su misión zurciendo unas con otras las actas de los mártires, harto uniformes y parecidas entre sí, de donde resulta un trabajo tan pesado como poco útil generalmente para la historia»24. Objetivamente, la única historia que se localiza en las Actas es la de Fructuoso, Eulogio y Augurio, refiriendo el jesuita Jean Bolland (1596-1665) que su festividad se celebra el 21 de enero, ratificando las expresiones de san Agustín en el sermón 273, de Aurelio Prudencio en el Peristephanon (Hymnus in honorem beatissimorum martyrum Fructuosi, episcopi ecclesiae Tarraco-

\footnotetext{
na Edad Media que asisten a los oficios divinos y oyen repetidamente a un clérigo hablar de ciertos términos que se vulgarizan y, luego, se sacralizan. Un ejemplo: Nemo es un santo (san Nadie) inventado a partir de un sermón de un clérigo francés, a finales del siglo XIII, que insistía en sus poderes a partir de la repetición -en latín- de unos versículos de san Juan (Secundum Ioannem, 3, 13 y 6, 44): Et nemo ascendit in caelum..., Nemo potest venire ad me...; «Nadie ha subido al cielo..., Nadie puede aceptarme...». Vid. A. ForCIONE, «El desposeimiento del ser en la literatura renacentista: Cervantes, Gracián y los desafíos de Nemo», en Nueva Revista de Filología Hispánica, 34 (1991) 654-690. J. MoYA, Las máscaras del santo. Subir a los altares antes de Trento, Madrid 2000, «Invenciones santorales», pp. 63-69.

24 Z. García Villada, Historia eclesiástica de España. I. El cristianismo durante la dominación romana, Madrid 1929, p. 259.
} 
nensis, et Augurii et Eulogii diaconorum, VI) ${ }^{25}$ y el Pasionario hispánico, aunque son relatos no proconsulares, escritos por algún testigo coetáneo a los acontecimientos y redactados a principios del siglo IV con términos típicamente africanos, muy arcaicos, como las palabras fraternitas (comunidad de fieles), refrigerium (que aparece también en las actas de santa Perpetua), statio (ayuno) ${ }^{26}$.

Estas actas son -señala Fábrega Grau- un extracto del protocolo oficial, siendo simplemente una narración de los hechos, o, tal vez mejor, una consignación ad perpetuam rei memoriam de las palabras que el obispo de Tarragona pronunció en los últimos momentos de su vida. Aunque el impacto de esta Passio dedicada a los mártires de Tarragona es menor que otras posteriores sobre la hagiografía peninsular, actúa como un modelo literario desde el momento en que recoge unas formas narrativas definitivas y un contenido que, con más o menos variantes, se irá reproduciendo en los relatos de los siglos IV, V y, asimismo, en los de la etapa visigoda ${ }^{27}$.

Tras la presentación de los hechos (Passio sanctorum..., 1), se centra la narración de Fructuoso en el diálogo que mantiene el obispo con los cónsules

\footnotetext{
25 A. Prudencio, Peristephanon. Himnos a los mártires, ed. M. J. Bayo, Madrid 1946; Obras completas de Aurelio Prudencio, ed. J. Guillén, Madrid 1950; Liber Peristephanon, ed. J. J. O’Donnell, Michigan 1993.

${ }^{26}$ Además de las obras citadas anteriormente, la muerte y festividad de los tres tarraconenses se reproduce más o menos ampliamente en el Oracional Visigótico, en la edición de J. Vives a partir de varios códices altomedievales de finales del siglo VII, principios del VIII y siglos IX y X, «Fructuosi, Augurii et Eulogii. XII kalendas februarias incipiunt orationes in diem sancti Fructuosi, Augurii et Eulogii», n. 446-468. Vid. Oracional Visigótico, ed. J. Vives, Barcelona (Monumenta Hispaniae Sacra I) 1946. Códice LXXXIX de la Biblioteca Capitular de Verona, n. 440. Códice Add. 30.852 del British Museum, n. 261. Breviarium de Cisneros, ed. 1502, n. 350 c. Breviario gótico, PL 86, n. 1055. ('n' = número de la oración).

27 Á. Fábrega Grau, Pasionario..., I, p. 87. C. Codoñer Merino, «Los escritores hispano cristianos», en Historia de España, dir. por R. Menéndez Pidal, Madrid 1974, I, p. 529, señala que las Actas de Fructuoso y sus compañeros Augurio y Eulogio son consulares, exceptuando los párrafos 5, 6 y 7, algo posteriores al año 313, con matices ingenuos y detalles triviales posiblemente con algún retoque posterior. Asimismo, Z. GARcía VilladA, pp. 260-265, considera que las Actas de Fructuoso son proconsulares; se recitarían públicamente tanto en Tarragona y otras comarcas de Hispania como en la Iglesia africana. Una de las categorías de las Actas de los mártires son las proconsulares, con mayor autoridad que otras y denominadas así porque contenían los procesos verbales oficiales que se guardaban en los archivos del procónsul. Vid. H. Delehaye, Les légendes hagiografiques, Bruxelles 1955, p. 126. La Passio Fructuosi fue conocida por Prudencio (Peristephanon, VI) y por Agustín de Hipona (Serm. 273 , in natali martyrum Fructuosi episcopi, Auguri et Eulogi diaconorum), de acuerdo con H. DELEHAYE, Les passions des martyrs et les genres littéraires, Bruxelles 1966, p. 104. Las noticias más detalladas sobre estos mártires se encuentran recogidas originalmente en las Actas de los mártires, pp. 781800) y en T. RUINART, Acta primorum martyrum sincera et selecta, Amstelaedami 1731, «Index actorum, passionum, etc.: Anno 259. Acta SS. Martyrum Fructuosi episcopi, Augurii et Eulogii diaconorum. Ex compluribus codd. Mss. Colbertinis 3. S. Germani a Pratis 2. S. Cornelii Compendiensis I. S. Benedictini Floriacensis I. RR.PP. Caelestinorum Parisiensium I. RR.PP. Fuliensium Parisiensum I. Illust. viri Boherii 2. S. Mariani Autisiodorensis I et aliis, cum editis collata».
}

Hispania Sacra, LX

121, enero-junio 2008, 9-46, ISSN: 0018-215-X 
Emiliano y Basso, que con la ayuda de los beneficiarios le conducen a la cárcel. La confrontación entre los próximos mártires, Fructuoso, Augurio y Eulogio, y el primer cónsul se refiere a la política religiosa romana cuando pregunta al obispo si sabe qué han mandado los emperadores (Audistis quid imperatores preceperunt?), ordenando que los tres fueran quemados vivos, et iussit sententia sua vivos ardere. La sentencia se cumple en el anfiteatro, pero cuando llega la muerte los tres compañeros se muestran felices y dignos de la promesa de las escrituras, consalatus igitur frater, ingressus est ad salutem insignis et ipso martirio felicibus, qui sanctorum Scripturarum fructus repromissionis sentiunt, y los fieles recogen las reliquias depositándolas en un sepulcro: Sed ne reliquas resuscitandas / et mox cum domino simul futuras / discretis loca diuidant sepulcris, / cernuntur niueis stolis amicti: / mandat restitui cauoque claudi / mixtim marmore puluerem sacrandum (Peristephanon, VI, vv. 136-141).

La historia de Fructuoso y sus diáconos marcará un rumbo novedoso en la historia eclesiástica desde el momento en que se configuran unos elementos movibles, capaces de ser transportados de un relato a otro. Con Fructuoso y los diáconos se iniciará la capitalización de los mártires por parte de las instituciones episcopales.. No en vano se ha considerado a este obispo, en algunos momentos de la historia, como el representante de la «altivez ibérica» ${ }^{28}$ frente a otros mártires reputados demasiado ambiguos por el rigorista Tertuliano. Un proceso doble, si se quiere inconsciente en los momentos de las persecuciones, se promoverá, en el ámbito visigodo y católico del siglo VII, cuando se establezcan definitivamente algunas sedes episcopales y, por otra parte, se relancen, inventen o reinterpreten algunas narraciones hagiográficas y martiriológicas, ubicadas en las duras persecuciones de finales del siglo III y principios del IV, para consolidar la categoría de las diócesis en función, precisamente, de unas estrategias totalizadoras en las que coincidirán la monarquía y la Iglesia, ambas representadas en los concilios visigodos.

Se abre el proceso con la aceptación popular de esos santos y mártires y su difusión en un medio semiurbano o semicampesino, mediante el enlace con la divinidad por medio de la sangre (el tormento que sufren los cristianos), el sudor (la tensión del interrogatorio ante el juez, cónsul o pretor y, paralelamente, el deseo del futuro mártir por refutar una antropología social y religiosa determinada) y las lágrimas (que vierten deudos y fieles en el momento inminente, recogida de cenizas o huesos, entierro, ceremonias sucesivas).

En principio este mecanismo dual se manifiesta en la monumentalidad, la creación de memorias martiriales, un martyrium, una lápida, una inscripción en el altar, para que luego, en un recuerdo permanente del aparato visual, se inicie

28 J. PÉrez de Urbel, Año cristiano, Burgos 1940, I, p. 106. 
una tradición oral, primero esotérica, posteriormente vulgarizada y finalmente sometida a la alta literatura ${ }^{29}$. Se busca con ello resolver el conflicto social entre la muerte del mártir y su aceptación, probablemente controlada, por los grupos sociales a los que se dirige la historia, condicionada casi siempre por los sectores afines a los episcopados.

Recientemente, Santiago Castellanos ha reseñado un doble proceso en la santidad altomedieval, relacionado con san Millán y la difusión de la Vita Aemiliani de Braulio de Zaragoza ${ }^{30}$. En un primer instante se destaca el papel desempeñado por los notables locales que recuren a la figura del santo, manifestándose la conexión entre los potentes locales y los líderes religiosos, subrayando que el patrocinio de las aristocracias con sus dependientes es similar al que, en el plano espiritual, ejerce el santo con respecto a las comunidad. Por otra parte, el mismo autor indica tres vectores en la configuración del «hombre santo» en el mundo tardoantiguo y en los primeros siglos medievales. Uno, la afluencia de gentes (multitudines) en torno al hombre santo. Dos, la tendencia de distintos sectores sociales hacia su figura (unanimitas). Tres, su consideración efectiva, una vez muerto, a través de su sepulcro, reliquias y locus (praesetia). Evidentemente, las fuentes directas de este proceso hablan de manera tangencial, es decir, desde unas consciencia y conciencia mediatizadas por la oficialización episcopal de un culto concreto. Sólo a partir de la Baja Edad Media y, sobre todo, a partir del Barroco contrarreformista del siglo XVII, se utilizarán las aportaciones visigodas y altomedievales para lanzar un discurso ingenuo sobre las listas y relaciones de obispos, por un lado, y, por otro, de mártires, santos, confesores, vírgenes y apóstoles, sumidos en unos tiempos demasiado oscuros, pero a la vez clarividentes en su utilización política, social y económica. La tardía divulgación de las actas, la aceptación de los pasionarios diversos por parte de la gente menuda, la vulgarización de esos modelos martiriales en ámbitos políticos y religiosos muy concretos (unificación religiosa de los visigodos, la presencia mozárabe o la repoblación del centro peninsular en el siglo XI), son elementos que vuelven a incidir en el conflicto entre una religión culta y dirigida y una religiosidad asumida por los hombres y las mujeres inexpertos en las tradiciones establecidas del cristianismo.

Parece observarse, tanto en el período de las persecuciones como en otros más tardíos una transformación en los discursos hagiográficos dirigidos bien a

29 Vid. F. Baños VAllejo, La hagiografía como género literario en la Edad Media: tipología de doce vidas individuales castellanas, Oviedo 1989. J. E. CONNOLly, A. DEYERMOND y B. DuTTON (eds.), Saints and their authors: Studies in Medieval Hispanic hagiography in honor of John K. Walsh, Madison 1990. G. PHILIPPART (dir.), Hagiographies: histoire internationale de la litterature hagiographique latine et vernaculaire en Occident des origins à 1550, Turnhout 1996.

30 S. Castellanos, Poder social, aristocracias y hombre santo en la Hispania visigoda, Logroño 1998, pp. 101-103; Hagiografía y sociedad en la España visigoda, Logroño 1999, p. 89.

Hispania Sacra, LX

121, enero-junio 2008, 9-46, ISSN: 0018-215-X 
la ciudad, bien al medio rural, o un cambio cuando la religiosidad pasa de ser un reducto limitado y adormecido en el medio rural a un ambiente más extenso, aunque en contacto con la economía agraria, que se manifiesta desde el siglo XI o principios del XII en el marco estrictamente urbano. Se mantiene siempre esa constante oposicional, pues al igual que abundan los mártires en el justo momento de la confrontación paganismo-cristianismo, también en períodos posteriores, la dominación islámica por ejemplo, se reproducirá la tensión entre dos modelos culturales y teológicos.

En este sentido, Kenneth Baxter Wolf, en un interesante estudio sobre los cristianos en Al Andalus, afirma que Eulogio y sus compañeros, al no ser mártires del antiguo reparto romano, se sitúan en el terreno de las inconsistencias entre el paradigma clásico y las circunstancias relacionadas con las ejecuciones de mediados del siglo IX, proyectando sobre los cristianos un modo de justificar su opinión acerca de los confesores, en el marco de una definición de la santidad que se veía contrarrestada por los intentos de algunos de mantener actitudes conciliadoras hacia las autoridades musulmanas de Córdoba ${ }^{31}$.

La aparición de estos «mártires voluntarios», unos cincuenta, entre los mandatos de Abd al-Rahman II y Muhammad I (850-859) acentuó la repulsa al mundo islámico entre los mozárabes, especialmente a partir de la difusión de las obras de Eulogio de Córdoba Memoriale Sanctorum, Documentum martyriale y Apologeticus Martyrum ${ }^{32}$. Que se buscaba el martirio, se supone, y que se pretendía su aceleración mediante la indiscreción política son una constante que se aprecia en los textos hagiográficos: «Era grande el despecho y rabia de los moros al ver que los cristianos con tanta frecuencia se presentaban al martirio, y llegaban a la osadía de ir a blasfemar públicamente de Mahoma en su mezquita ${ }^{33}$.

La confrontación entre dos culturas vuelve a emerger en la historiografía, las asimilaciones y procesos recíprocos entre dos religiosidades medievales retornan constantemente. Se trata, en definitiva, de plantear, como hizo Raoul Manselli, una propuesta metodológica en el análisis de la santidad, los santos, mártires, vírgenes, patronos, etc. en una religión popular que se manifiesta como una realidad viva, múltiple y compleja cuya existencia apenas se analiza su: «Parece establecerse que la religión popular y la religión de cuantos culturalmente son inexpertos deben contentarse con lo más simple, más obvio, más elemental que

${ }^{31}$ K. B. Wolf, Christian martyrs in Muslim Spain, Cambridge 1998, p. 3. Como ejemplo sirva la reinterpretación de una leyenda medieval sobre el martirio de dos clérigos mozárabes, Leonardo y Nicolás, bajo la dominación de los musulmanes. Vid. Á. BARRIOS GARCíA, «La leyenda medieval de los mártires de Ledesma», en Salamanca. Revista de Estudios, 43 (1999) 193-233.

32 Obras completas de San Eulogio, ed. M. Jesús Aldana García, Córdoba 1998.

${ }^{33}$ Actas de los mártires. Persecución de los musulmanes, s.f. (finales siglo XIX), p. 162. Biblioteca del Archivo Diocesano de Ávila. 
ofrece el cristianismo, una religiosidad alejada de la compleja formulación dogmática, de la discusión teológica, de la distinción sutil y abierta, más bien cercana al mundo de los sentimientos inmediatos -la alegría, el dolor, la muerte- y a los acontecimientos sencillos de la vida - el nacimiento, la boda, la enfermedad y, ¿por qué no?, el milagro. (...) La religiosidad popular parece abierta a los aspectos más inmediatos de la vida cotidiana, a los hábitos mentales de la tradición particular, a las costumbres del pasado, aunque no sea cristiano, en un plano totalmente distinto al de la religión culta, aunque, de tanto en tanto, parecen encontrarse. La presencia de ciertas costumbres paganas sobre el plano de la religión popular corresponde a la influencia del neoplatonismo sobre el plano de la religión culta» ${ }^{34}$.

De manera casi oculta, el santo o el mártir que surge de las actas o de los pasionarios encierra una sociabilidad, que aparece exclusivamente tras la muerte y la consolidación de un locus. Como ha señalado acertadamente J. Moya, «el hombre santo es un segregado de la masa, predestinado por Dios para llevar un género de vida aparte» ${ }^{35}$. El aislamiento social del santo se corresponde con las cualidades únicas que se presumen en su cuerpo muerto. Se halla este dotado, según reseña el obispo de Jaén Sancho Dávila, cuatro disposiciones inaccesibles para el resto de los mortales. La primera es la impasibilidad: «calidad y buena disposición por la qual no podrán recibir alteración alguna». La segunda es la claridad: «luz y resplandor tan grandes que estos cuerpos dan de sí que en su comparación será escura la del sol». La tercera, la agilidad: «en orden al movimiento de los dichos cuerpos, haziéndoles ábiles...que también les abilita para qualesquiera otros mouimientos apresurados». La cuarta, es la sutilidad: «sus cuerpos... lo serán a semejanza de los espíritus, según la subtilidad que estos tienen en orden al mouimiento» ${ }^{36}$.

Aunque la veneración pública se manifiesta tardíamente (como en el caso de Vicente, Sabina y Cristeta), la existencia remota de un acontecimiento deja su huella en las mentalidades y en la topografía del enclave urbano o rural. No interesa tanto el origen del santo como el modelo que se establece posteriormente, pues numerosos cultos locales relacionados con mártires son anteriores a la redacción de un aparato litúrgico de la época visigoda o de los siglos X y XI. En este sentido se podrán comprobar las relaciones entre el origen topográfico de los mártires abulenses Vicente, Sabina y Cristeta y su historia posterior.

\footnotetext{
${ }^{34}$ R. MANSELLI, «La religione popolare nel Medio Evo: prime consideración metodologiche», en Nuova Rivista Storica, LVIII (1974) 33; La religione popolare nel Medioevo (sec. VI-XII), Torino 1974. G. J. CunNING y D. BAKER, Popular belief and practice, Cambridge (Studies en Church History) 1972.

35 J. MoYa, p. 32.

${ }^{36}$ S. DÁvILA, De la veneración que se debe a los cuerpos de los sanctos y a sus reliquias..., Madrid 1611, Lib. III, cap. XI, pp. 349-350. 
El hecho de hablar o escribir sobre los «mártires abulenses», aun reconociendo su procedencia extraña (Talavera o Évora), vendría a confirmar la tesis sobre la posesión de los cuerpos santos más que sobre su ubicación natural. De ahí derivará la polémica, por ejemplo, sobre la propiedad de algunos mártires en distintos períodos históricos o acerca de la invención de personajes relacionados con la santidad y vinculados tardíamente a santos con sus propias raíces: sería el caso de santa Victoria, identificada con su hermano san Acisclo, o Eulalia de Barcelona (en contraposición o semejanza con la de Mérida), sobre el origen natal de Emeterio y Celedonio o Vicente, Sabina y Cristeta de Ávila.

Formalizadas las actas, su divulgación provocará la aparición de numerosas transcripciones que pretenden seguir el guión marcado sobre mártires concretos o sobre mártires apócrifos. Como se puede apreciar, los mártires hispánicos son escasos en la anterior relación, destacando únicamente Vicente de Zaragoza, martirizado en Valencia, con una presencia notable asimismo en el Peristephanon de Aurelio Prudencio (Himno V). La formación de un Pasionario hispánico en la época altomedieval aumentará el número de mártires, todos ellos, excepto Fructuoso, Augurio y Eulogio, ubicados en las persecuciones del siglo III y primeros años de la centuria siguiente: Acisclo y Victoria, Facundo y Primitivo, Leocadia de Toledo, Eulalia de Mérida, Vicente de Zaragoza, Eulalia de Barcelona, Emeterio y Celedonio, Torcuato y compañeros, Justa y Rufina de Sevilla, Cucufate de Barcelona, Félix de Gerona, Justo y Pastor de Alcalá de Henares, Fausto, Jenaro y Marcial, Servando y Germano, Vicente, Sabina y Cristeta de Ávila e Innumerables de Zaragoza.

En total, veinticinco mártires identificados y un número indeterminado que se disimulan con términos como «compañeros» o «innumerables». Más tarde, en 1689, Ruinart recogerá exclusivamente las actas de Fructuoso y los diáconos (In Acta sanctorum Fructuosi, Eulogii et Augurii martyrum), san Marcelo de Tánger (In Acta sancti Marcelli martyris Tingitani), cuyo cuerpo -según Tamayo Salazar en el Martirologio hispánico- es trasladado en 1493 a la ciudad de León; san Vicente de Zaragoza (In martyrium sancti Vincentii. Passio sancti Vincentii levitae), señalándose que no se puede confundir con otro Vicente que sufrió persecución bajo el pretor Daciano con sus hermanas vírgenes Sabina y Cristeta en Ávila ${ }^{37}$; santa Eulalia (In martyrium S. Eulaliae virginis), celebrada tanto por los emeritenses como por los barceloneses ${ }^{38} \mathrm{y}$, por último, los «Innumerables» de Zaragoza (De SS. XVII martyribus Caesargustannanis) a partir

${ }^{37}$ Anonnulis etiam male confunditur noster Vincentius cum altero Vincentio, qua sub eadem persecutionem eodem Daciano praeside cum sororibus suis virginibus Sabina \& Christeta martyrum Abulae consumavit, T. RUINART, p. 366.

38 «Duplex Eulalia virgo et mártir apud hispanos vulgo celebratur, quarum nuam Emeritensis, alteram Barcinonenses sibi vindicant», ibidem. 
del himno de Prudencio. En total podrían ser unos cincuenta los mártires adjudicados a Hispania, según Hippolyte Delehaye ${ }^{39}$, aunque para el siglo X el hagiólogo Díaz y Díaz contabiliza unos diez textos hagiográficos, incrementándose hasta los treinta en el siglo XII gracias a la incorporación de numerosos obispos como Raimundo de Roda, Pedro de Osma, Odón de Urgell, etc. y algunos abades.

Paralelamente a la inundación de mártires, se va formando y consolidando lentamente en la península Ibérica la organización metropolitana en la época romanocristiana. Si bien no se alude a la ciudad de Ávila ni al nombre del obispo o presbítero, los cronistas abulenses (Cianca, Ariz, González Dávila, Tello Martínez) dan por entendido que la ciudad tenía su propio prelado cuando se escribe que «en el número de los obispos se tiene ser comprendido el de la Yglesia de Ávila», o se cuenta la «concurrencia del de la Yglesia de Ávila, pero ignoran el nombre».

Contando con la escasa penetración del cristianismo en el centro peninsular, hay que destacar dos aspectos interesantes del Concilio de Elvira celebrado a principios del siglo IV. Por una parte, la extensión del paganismo romano y de las religiones de origen indígena. Por otra, los cánones anti-judíos a los que la institución eclesiástica mantiene apartados. Estos dos datos_permitirán encuadrar en su justo contexto algunas narraciones hagiográficas de la misma época, considerando siempre que el primitivo cristianismo hispánico recuerda demasiado las vicisitudes creadas por el asentamiento de esta nueva religión en las áreas más romanizadas de finales del siglo I e inicios del siguiente. Así pues, a Hispania el cristianismo llega con notable retraso, localizándose todavía sacrificios sacrílegos con la efusión de sangre de toros y carneros ${ }^{40}$.

Las Circunstancias históRicas de la Passio VinCENTII, SAbinae et CRISTETAE...

La hagiografía de los mártires abulenses no es particular ni exclusiva. Se inscribe en un género literario que presenta numerosos problemas de redacción, adaptación y difusión. Se recurre a un modelo o estereotipo de santo, constante en las compilaciones medievales del mundo visigodo y, en general, anteriores al

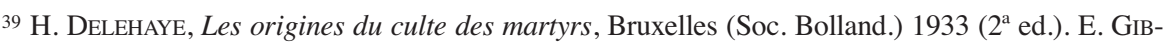
BON, Historia de la decadencia y caída del Imperio Romano, ed. D.A. Saunders, Barcelona 2000, p. 243, considera que fueron unos dos mil los cristianos martirizados en las persecuciones de Diocleciano.

${ }^{40}$ Dum... euangelica eruditio sensim atque gradatim apostolorum doctrina in omnem terram refulgiste sero tandem in Spaniae finibus innotuit; eratque rara fudes, et ideo magna, quia rara. Delubra vero gentilium in omni loco sacrílega effusione sanguinem taurorum hircorumque fumabant, H. QUEN$\mathrm{TIN}$, Les martyrologies historiques du Moyen Âge. Etude sur la formation de martirologe romain, Paris 1908, p. 145

Hispania Sacra, LX

121, enero-junio 2008, 9-46, ISSN: 0018-215-X 
siglo XIII, realizadas por categorías (santos, mártires, varones apostólicos, jóvenes vírgenes, obispos, etc.), y destinadas a reunir una determinada condición de acontecimientos extraordinarios. Hay que establecer los méritos, los valores, las formas de vida de un santo, el reparto de las reliquias, los milagros realizados en vida y después de la muerte. Existe una coherencia interna en todo relato hagiográfico y martiriológico explicada a partir de un modelo común de la Antigüedad tardía. Por todas estas circunstancias, las vidas transmitidas de los mártires de Ávila, en sus planteamientos generales, no ofrecen sorpresas destacadas, aunque sí dos o tres notas sumamente originales en el episodio de los tormentos y en la ubicación de los mismos.

Aparte de algunas destacadas piezas hagiográficas de gran éxito entre los mozárabes durante los primeros siglos de la dominación musulmana, como las Vitae sanctorum patrum Emeritensium, la Vita sancti Aemiliani de Braulio de Zaragoza o la Vita Fructuosi Bracarensis ${ }^{41}$, entre los mártires puramente hispanos sobresale Vicente de Zaragoza. Las noticias de este levita (un eclesiástico con rango inferior al sacerdocio) se localizan en el Himno V de Aurelio Prudencio (Passsio sancti Vincenti martyris) y en una pasión de carácter épico, la Passio sancti ac beatissimi Vincentii levite martyris Christi, qui passus est Valentia in civitate sub Datiano preside; XI kalendas februarias ${ }^{42}$. Asimismo, en las Actas de los mártires, en los sermones de san Agustín ${ }^{43}$, Ruinart44 (Anno 304. Passio S. Vincentii Levitae \& martyris), y en la España sagrada (T. VIII) del agustino Enrique Flórez.

$\mathrm{Su}$ culto es tan antiguo que parece que estuvo generalizado por todo el Imperio romano, figurando en el Martirologio jerominiano y en el Calendario de Cartago, siendo exaltado por Paulino de Nola, Avito, Venancio Fortunado, Gregorio de Tours, etc. ${ }^{45}$. Sin duda, Vicente de Zaragoza se convierte en el

\footnotetext{
${ }^{41}$ Bibliotheca Hagiographica Latina, 2.530, 100 y 3.194.

42 Pasionario hispánico. II. Textos, pp. 187-196. Vid. C. GARcía RodríGuez, El culto de los santos en la España romana y visigoda, Madrid 1966, p. 257.

${ }^{43}$ Actas de los mártires, pp. 995-1017; los sermones de san Agustín en la misma obra, pp. 10181023 .

44 «Ex editis, et codd. Mss. Bibliothecae Colbertinae 3. S. Germani a Pratis 7. Illustriss. Abatís de Noaliis 2. Monasterii Claraevallensis I. Illustriss. Boheri 2. Monasterii S. Petri Pratellensis I. S. Mariani Autisiodorensis I. Monasterii B. Marcae Calensis I. RR.PP. Caelestonorum Parisiensium I. RR.PP. Carmelitarum excalceatorum Paris. 2 B. Mariae Regiae de Malodumo prope Pontisaram, nunc Fuliensium Paris I,. etc.». Indica, además, Theodorici Ruinart que la Passio de Vicente se recoge en el sermón 275 de san Agustín («Passio S. Vincentii ab Augustino laudata»), celebrándose su festividad el 22 de enero, según Bolland y otros códices manuscritos, en los Himnos de Prudencio, en los martirologios latinos, Gregorio Turonensis, lib. 3, Historiae francorum, cap. 29, y Tamayo Salazar en el Martirologio hispánico.

${ }^{45}$ R. García Villoslada (dir.), Historia de la Iglesia en España. I. La Iglesia en la España romana y visigoda (siglos I-VIII), Madrid 1979, pp. 65-68.
} 
mártir modélico de las persecuciones de Diocleciano, en la imagen simbólica que tratará de ser imitada por otros relatos, algunas toponimias y numerosas festividades.

Una narración original amplificada establece los numerosos detalles acerca del martirio, el hundimiento del cuerpo en el mar, su venturoso regreso a una playa y la tradición creada a partir de esta aparatosa historia. Será normal que Vicente, el vencedor, derive en santos duplicados y homónimos. De hecho, numerosas oraciones, varios oficios y algunas costumbres litúrgicas y festivas tanto peninsulares como francesas tendrán su origen en este peculiar modelo vicentino. Desde el punto de vista litúrgico, la festividad de san Vicente de Zaragoza se recoge en el Oracional visigótico, desarrollando las oraciones, antífonas, responsorios y alleluiáticos empleados fundamentalmente en los monasterios ${ }^{46}$.

Como imagen hagiográfica, la vida y muerte del levita Vicente tendrá amplias repercusiones, incidiendo particularmente en la Passio de los mártires abulenses. La idealización de este molde martirial, difundido desde el siglo IV y relacionado con los otros grandes diáconos Esteban y Lorenzo, entra de lleno en los límites del estereotipo del testigo cristiano. San Vicente de Zaragoza se convierte, pues, en un argumento de otras vidas literarias. Al igual que otros mártires, Vicente será un instrumento de la divinidad; su cuerpo, objeto de búsqueda y veneración en sus restos.

Hijo de Eutricio (Eutychio) y Enola, de Osca (vulgo Huesca, cuius episcopus olim Tarraconensi, nunc caesaraugustano Archiepiscopo suffragantur), estudia bajo la dirección de Valero, obispo de Zaragoza (a Valero episcopo fit diaconus), que será desterrado por orden de Daciano. Otra posibilidad, aunque remota y escasamente fundamentada, sobre la cualidad profesional de Vicente es reseñada por Antonio Tovar y José M. ${ }^{a}$ Blázquez cuando indican su pertenencia al elemento militar. Su proceso está caracterizado por la actitud radicalizada del pretor Daciano, aunque hay que considerar que las actas de este mártir no son auténticas ni contemporáneas, sino posteriores al Himno V de Aurelio Prudencio. El romano constantemente está fuera de sí por la ira, iamque prae ira paene extra se positus (Passio, V). El viaje hacia la muerte está perfectamente descrito en las Actas y en los martirologios de Usuardo y Lyon.

\footnotetext{
46 Oracional Visigótico, op. cit., n. 469-495. Códice Veronense, n. 463. Códice Londinense, n. 284. Breviarium de 1502, n. 339a. Libellus orationum de Bianchini, n. 58. Breviario gótico, PL, n. 1068. Otras fuentes: «I. 22. Natale sancti Vincencii», fol. 71 del ms. 815 de la Biblioteca de Montserrat. Vid. Pontifical de Braga, ms. 1134, Biblioteca Pública de Oporto, fol. 106. Vid. J. O. BRAGANÇA, «A liturgia da Braga», en Hispania Sacra, 17 (1964) 259-281. «Officium in diem sancti Vincentii laevite», fol. 96 v; Antifonario de la Catedral de León. J. VIVES, «El santoral de los calendarios de San Cugat del Vallés», en Hispania Sacra, 51-52 (1973-1974) 247-269.
}

Hispania Sacra, LX

121, enero-junio 2008, 9-46, ISSN: 0018-215-X 
El relato es recogido posteriormente, en el siglo XIII, por el dominico Jaccopo de Varazze en la Legenda Aurea, anotándose que el santo fue «quemador de vicios, en cuanto que por medio de la mortificación corporal prendió fuego a las indicaciones desordenadas y logró reducirlas a pavesas; extintor de incendios, en cuanto que con la fortaleza con que soportó las pruebas a que fue sometido, apagó las llamas de los tormentos que sus perseguidores le aplicaron; y victorioso, en cuanto que con su desprecio del mundo se alzó con las victorias sobre sus engaños atractivos; el mundo, en efecto, trató de seducirle con tres señuelos, a saber: el de las falsas doctrinas, el de los amores terrenos y carnales y el de los mundanos temores» ${ }^{47}$. Como en otros casos, el fraile dominico emplea abusivamente una técnica de reelaboración en los diálogos, intentando fundamentar la autoridad patrística a partir de un texto alejado evidentemente del relato original ${ }^{48}$.

Más breve y más ajustadamente a la literatura hagiográfica procedente de las Actas, T. Ruinart desarrolla los testimonios del mártir en Valencia a partir de unos epígrafes que se refieren al apresamiento e interrogatorio, las respuestas de Vicente, la ausencia verbal de Valero, los tormentos sufridos y, por último, la muerte y el sepelio final ${ }^{49}$.

La popularidad y vulgarización del santo de Zaragoza procede del Himno V de Aurelio Prudencio, un poeta que surge como un «heraldo de oscuridad» al sostener que el origen del mal en el mundo se debe a un espíritu pecador, «que este espíritu pecador ha ocasionado la corrupción de la humanidad y que la corrupción de la humanidad ha traído consigo la de la naturaleza» ${ }^{50}$, en contraposición a un Paraíso cubierto por rosas purpúreas, humedecido por fuentes y rico en flores y aromas (vv. 113-116). La obsesión de Prudencio por el mal le lleva a la consideración de Daciano como su representante en la tierra, la tortura como

${ }^{47}$ S. de la Vorágine, La Leyenda dorada, Madrid 1996, I, pp. 120-123. El dominico se inspira sobre todo en la narración de Agustín de Hipona: «Hemos contemplado un gran espectáculo con los ojos de la fe: al mártir san Vicente, vencedor en todo. Venció en las palabras y venció en los tormentos, venció en la confesión y venció en la tribulación, venció abrasado por el fuego y venció al ser arrojado a las olas, venció, finalmente, al ser atormentado y venció al morir por la fe» (Sermón 274, «Sobre el martirio de san Vicente»: PL 38, 1252).

48 Vid. S. BERTINI GUIDETTI, «Scrittura, oralità, memoria. La Legenda aurea fonte e modello nei sermones e nella Chronica civitatis Ianuensis di Iacopo da Varagine», en De la sainteté a l'hagiographie. Genèse et usage de la Légende Dorée, Genève 2001, pp. 128-129.

49 «Uterque a Daciano apprehensus. Valentiam ducit. A Daciano interrogati. Vicentius respondet. Confer Prud. P. 15. Valerius in exilium muttitur. Torquetur Vicentius. Rurfus novis tormentis applicatur. Frustra a tyrano tentatur. Novis afficitur tormentis. Includitur in locum horridum. Qui caelitus mutatur. Custodes in Christum credunt. In lecto depositus obit. Corpus seris objectum mire servatur. Frustra in mare re dejicitur. Corpus martyre revelante inventum. Cum honore sepelitur. SS. Trinitas». T. RUINART, 366-373.

${ }^{50}$ B. Farrington, Ciencia y política en el mundo antiguo, Madrid 1973, pp. 46-47. 
su medio de actuación y la muerte del cristiano como la única solución para alejarse del infierno. En efecto, Vicente es sometido a un interrogatorio y a toda clase de torturas que el poeta describe con minuciosidad: Tormenta, carcer, ungula / strindensque flammis lamina / atque ipsa poenarum ultima, / mors, christiani ludus est (vv. 61-64).

La doble maldad del torturador, inflingir sufrimiento, el placer del martirio, se manifiesta en Daciano cuando ordena que los verdugos aten a Vicente, retorciendo sus brazos extendidos de arriba y abajo, descoyuntando sus miembros, golpeándole, abriendo el torso y dejando el hígado al descubierto mientras que los garfios le penetran profundamente (vv. 109-120). Más tarde la ira de Daciano aumenta al ver que el reo se alegra, ríe y provoca, mostrando, como afirman numerosos autores cristianos, la «alegría de los mártires», la «apología de la verdad de la religión cristiana». Luego, el levita será encerrado en el lugar más negro de la prisión, el infierno sin luz, exhalando su último suspiro y defraudando la rabia del tirano, una muerte que, según García Villada ${ }^{51}$, procede de alguna tradición oral relativamente extendida y que Prudencio incorpora al Himno V de su Peristephanon.

Los milagros que preceden a la muerte del mártir reflejan su propia superioridad, capaz de convencer, es decir, convertir a los esbirros que custodian al santo. El cadáver será expuesto a las fieras y aves para que los cristianos no obtengan reliquias y, así, no sea reivindicado como mártir, mientras que un cuervo negro custodia el cuerpo impidiendo que un enorme lobo devore los restos. Un pretor abatido se ve impotente para enfrentarse con el muerto, reconociendo que con su crueldad le hace más glorioso, cum enim eum acrius saeuiens persequor, gloriosiorem mea saeuitia factio (Passio, XI) y decidiendo llevar a Vicente a los profundos abismos del mar hasta que es recogido por la viuda Jónica y transportado a una pequeña basílica. La llegada del cuerpo marinero de san Vicente indicará la sacralización de un espacio estratégico, el Hierón Akrotérion citado por Estrabón (III, I, 3), el Cabo Sagrado o Cabo de San Vicente, sobre el que se levantará la ermita del Cuervo y luego el convento de San Vicente, arruinado ya a finales del siglo XIX.

Identificado Vicente con los hermanos Macabeos, su cuerpo y alma disfrutarán de la gloria. No hay que olvidar, por otra parte, que el propio relato hagiográfico de Vicente, Sabina y Cristeta es deudor de las numerosas narraciones sobre Vicente de Zaragoza. La popularidad medieval de este santo se incorporó literariamente en la Leyenda dorada de Santiago de la Vorágine. Las analogías entre ambos Vicentes ya fueron apuntadas por el beneficiado Bartolomé Fernández Valencia en el siglo XVII: «Fue en todo semejante este sagrado martirio de san Vicente de Ávila al de otro san Vicente de Valencia: el uno fue español,

51 Z. García Villada, 279-282.

Hispania Sacra, LX

121, enero-junio 2008, 9-46, ISSN: 0018-215-X 
el otro también; el uno fue martirizado por Daciano, el otro también padeció por mandato de este inicuo presidente; padeció aquél grandes trabajos en el camino desde Zaragoza a Valencia, éste los padeció no menores desde Talavera a Ávila...»52.

Sobre las vidas de los mártires se acopian únicamente noticias arqueológicas y cultos paralelos no oficializados, pues todavía no figuran en el himnario, el oracional y el sacramentario. Sólo una documentación sobre el obispo Fructuoso y sus diáconos, Eulalia de Mérida, Acisclo de Córdoba, Vicente de Zaragoza y otros aparecen en la literatura tardorromana o en los primeros momentos de la dominación visigoda. Fructuoso, Augurio y Eulogio se localizan en el Himno VI de Prudencio; Acisclo (sin santa Victoria) en el Himno IV (Corduba Acisclum dabit et Zollum tresque coronas, vv. 19-20), Eulalia de Mérida en el III (Himnus in honorem passionis Eulaliae, beatissimae martyris); Vicente de Zaragoza en el Himno V y en los sermones de Agustín de Hipona; Emeterio y Celedonio en el Himno I (Hymnus in honorem sanctorum martyrum Emeterii et Chelidonii Calagurritanorum); sobre san Cugat hay una referencia en el poeta cristiano cuando afirma que la esclarecida Barcelona se levantará alegre con Cucufate, Barchinon claro Cucufate freta (IV, v. 36), lo mismo que Gerona con san Félix (IV, vv. 29-30) y Alcalá de Henares con los santos Justo y Pastor (IV, vv. 41-44) al relatar Prudencio en dicho himno la muerte de los mártires zaragozanos (Hymnus in honorem sanctorum decem et octo martyrum Caesaraugustanorum). Los santos no citados, como Victoria de Córdoba, Facundo y Primitivo, Leocadia de Toledo, Eulalia de Barcelona, los «Varones Apostólicos», Justa y Rufina de Sevilla, Fausto, Jenaro y Marcial, Servando y Germano y, finalmente, Vicente, Sabina y Cristeta de Ávila tendrán que esperar unas décadas para que sus vidas y muertes sean recogidas de forma escrita por la liturgia hispana. Claro que otros citados y con un culto relativamente extendido en Barcelona y alrededores, como Cucufate, desaparecen repentinamente del nuevo Martirologio universal de la Iglesia católica (2001) porque el número exorbitante de santos oscurecía la «centralidad» de Cristo.

Las actas de los mártires son la transcripción aproximada de los procesos verbales, hecha por los paganos y conservado en archivos oficiales, aunque estas actas denominadas acta forensia o acta iudiciorum son extremadamente raras. Al no tener constancia directa sobre numerosos mártires, los cristianos de los siglos IV y V fueron elaborando una tradición oral que, posiblemente, se trasladaría en un ámbito estrictamente local a algunos calendarios que conmemoraban las fiestas y aniversarios de cada iglesia particular. Las narraciones semioficiales sobre algunos sujetos venerados se incorporarían a un pasionario, es decir, a una colección hagiográfico-litúrgica con el nombre de Passionarium o

${ }^{52}$ Historia de San Vicente y grandezas de Ávila, ed. T. SoвRino CHомón. Ávila 1992, p. 199. 
Liber Passionum que recogía actas ${ }^{53}$, pasiones de mártires que se leían en la misa o en el oficio nocturno de cada aniversario.

Todavía en la alta Edad Media, se fueron redactando en el mundo europeo algunos martirologios generales como el de Beda el Venerable (año 735), el de Lyon (anterior al año 806), el Romano y los de Floro, Usuardo y Adón, todos ellos posteriores al Martyrologus Hieronymianum, conservado en manuscritos del siglo VII y con una composición dudosa que se remonta al siglo V, cuyo texto de la séptima centuria se supone que es paralelo al de los calendarios españoles escritos en el mismo tiempo ${ }^{54}$.

Frente a todos los relatos que aportan noticias más o menos precisas sobre mártires, santos y confesores, aparecerá más tarde el legendario, un texto que, según la historia eclesiástica, no pasa de ser un libro destinado exclusivamente a la lectura piadosa popularizada a partir del siglo XIV, relacionado, en el caso de España, con la pervivencia de algunos legendarios mozárabes que constituían solo trozos de una lectura espiritual, la lectio sacra.

La transmisión de unos sucesos (reales o imaginarios) convertidos en leyenda y su oficialización en los textos es un proceso lento, pues el Pasionario constituye un texto móvil, capaz de ir asimilando viejas tradiciones y nuevos relatos surgidos en la etapa altomedieval. La realidad de los personajes Vicente, Sabina y Cristeta procede, probablemente, de algún documento arqueológico paleocristiano o visigodo. La escasez de noticias y el recuerdo permanente de la muerte, caracterizarían la posterior formación de un relato escrito procedente de una Passio de común, es decir, un conjunto de actas, no proconsulares sino elaboradas a partir de unos rasgos comunes de varios mártires, individualizándose cada una de ellas en el siglo VII y en décadas posteriores.

Este proceso de amplificación de una narración desde unos hechos precisos y poco documentados hace que surja el partidismo en el relato. A partir de una Passio común o de alguna similar a la del mártir que tenía que recibir una autoridad escrita, se fue componiendo la Passio sancti Vincentii, Sabinae et Christetae... en el transcurso del siglo VII. Ahora bien, en cualquier Passio hay que diferenciar, en la formación del relato hagiográfico, dos aspectos. Primero, el propio proceso verbal del interrogatorio de Daciano a Vicente, similar a otras pasiones, los acontecimientos concomitantes con el arresto, la prisión, los tormentos y la muerte. Segundo, si el relato procede de algún testigo directo no muy lejano o, por el contrario, si se trata de una narración posterior, distinguiendo entonces si se aporta una documentación (oral, arqueológica, literaria) digna de consideración o bien, a la inversa obedece a una especie de narración

${ }^{53}$ H. FLóREZ, T. XVIII, 337.

${ }^{54}$ Z. García VilLADA, 290.

Hispania Sacra, LX

121, enero-junio 2008, 9-46, ISSN: 0018-215-X 
novelesca, amplificada y vulgarizada a partir de un tronco común y con elementos más o menos fantásticos.

Antes del siglo VII acaso existiera un culto local relacionado con los mártires Vicente, Sabina y Cristeta. Una tradición oral, que se iría degradando desde la Antigüedad tardía, se ve recuperada en la primera mitad del siglo VII por algún texto litúrgico con fórmulas generales, vagas e imprecisas que agruparían las vidas y martirios de algunos santos como Leocadia de Toledo, Félix de Gerona, Cucufate y Eulalia de Barcelona, Innumerables de Zaragoza, Justo y Pastor de Complutum y Vicente, Sabina y Cristeta de Ávila. De manera muy lenta se fueron especificando los relatos, pormenorizando algunos detalles concretos, verídicos o fantásticos, sobre cada individuo. La pasión de san Vicente de Zaragoza se convertirá en el estereotipo para aquellos relatos que surgen en el siglo VII, cuando aparece una Passio de communi que se relaciona con el conocimiento y difusión del culto a san Saturnino y sus actas a partir del año 592 en conexión con la dominación bizantina de parte de la Península, guardando una estrecha afinidad entre la pasión de este santo y la recensión Leocadia-Vicente, Sabina y Cristeta. Las relaciones de estos últimos con Cucufate, Félix de Gerona y otros se aprecia en la disposición interna de cada pasión y, sobre todo, en la figura de Daciano, que sirve para articular todas las narraciones. Además, se puede ligar estrechamente la Passio de Leocadia de Toledo con la de los mártires abulenses por medio de la amplia introducción del texto, previa a la formación específica de una narrativa concreta sobre los santos de Ávila. La formación del pasionario pormenorizado sobre Vicente y sus hermanas, a finales del siglo VII, sirvió para su uso en las celebraciones litúrgicas mediante el relato de unos sucesos modélicos que ilustraban y formaban la fe de los escasos devotos establecidos en la ciudad.

Así pues, la génesis del discurso hagiográfico de los hermanos en el mundo altomedieval se explica a partir de un tronco común para varias pasiones, la de Vicente de Zaragoza. Luego, se estructura una Passio de communi que relaciona, en un mismo relato literario, la corta vida y la amplia muerte de varios mártires. Paralelamente, sobre un acontecimiento heroico y escasamente difundido (el propio martirio de los tres lusitanos), arranca un proceso triple desde el instante en que la cultura eclesiástica más ortodoxa trata de destruir un recuerdo acaso más relacionado con Prisciliano que con los mártires, inutilizar mediante una superposición literaria y litúrgica algún monumento pagano (indígena) o herético, desnaturalizando todo un ambiente procedente del siglo IV mediante una nueva significación de los sustitutos cristianos. Empresa que, por otra parte, es característica de la cultura eclesiástica de la Alta Edad Media cuando se actuaba contra la contaminación que algunos movimientos religiosos (bagaudas, arrianismo, priscilianismo, pelagianismo, etc.) ejercían en la cultura clerical, acentuándose -como señaló acertadamente Jacques Le Goff- el monopolio clerical de la cultura y la vida. 
M. Cecilio Díaz y Díaz apunta que la pasión de los santos de Ávila Vicente, Sabina y Cristeta pudiera haber sido utilizada en el Bierzo por Valerio y en Braga por el autor de la Vita Fructuos i55. Esta última recopilación parece que fue redactada hacia el año 680 en los alrededores de la ciudad portuguesa por un escritor mediocre desconocido, intentando promocionar la devoción a san Fructuoso, una pieza de edificación que será insertada por Valerius Bergidensis en su compilación hagiográfica. Seguramente, por necesidades litúrgicas, el género hagiográfico se desarrolla en el siglo VII, redactándose al menos ocho pasiones (entre ellas la de los hermanos abulenses) dependientes tanto de las tradiciones locales como de la influencia de la obra poética de Prudencio y la Passio de Vicente de Zaragoza.

Puede sorprender el amplio elenco de mártires hispánicos en los primeros siglos del cristianismo. Ahora bien, frente al mundo merovingio ${ }^{56}$, la elaboración hagiográfica peninsular parece bastante pobre, destacando únicamente una trama general que, más o menos ampliada, se repetirá tanto en la literatura mozárabe como en los otros siglos medievales. Así, en la compilación atribuida a Valerio del Bierzo, aunque de varias manos de los siglos X y XI, se registran parcialmente la Vita sancti Iohannis, la Vita sancti Paulinis, De sancto Serapione, la Vita Fructuosi y otras, sin mencionar ningún mártir del ciclo de Diocleciano. La Passio Vincentii, Sabinae et Christetae suponía, por otra parte, las de Cucufate de Barcelona, Justo y Pastor de Alcalá y Félix de Gerona. Sin embargo, el culto a los mártires se mantiene en unos términos estrictamente locales en las centurias posteriores a la invasión musulmana.

Una conclusión avanzada por Á. Fábrega se establece de la siguiente forma: «Vicente y sus hermanas Sabina y Cristeta, de Ávila, tienen como pasión propia el mismo texto de común, caso idéntico al de santa Leocadia, con el correspondiente apéndice pobre que su autor, tal vez, sacó de la tradición local. En él finge su procedencia de Ebora donde fue juzgado: a instancias de sus desoladas hermanas que entablan un diálogo con el mártir en la cárcel (dependencias claras con la pasión de san Félix), huye con ellas hacia Ávila, donde mueren los tres. Su composición puede atribuirse con toda probabilidad a la mitad del siglo VII. Tiene otro apéndice que ofrece indicios de haber sido verosímilmente redactado a finales de este mismo siglo o principios del siguiente» ${ }^{57}$.

55 M. C. DíAZ Y DíAZ, «Passionnaires, légendiers et compilations hagiographiques dans le Haut Moyen Âge espagnol», en Hagiographie, cultures et sociétés, IV-XII siècles. Actes du colloque organisé à Nanterre et à Paris (2-5 mai, 1979), París 1981, pp. 58-59. Vid. «La compilación hagiográfica de Valerio del Bierzo» y «Un nuevo códice de Valerio del Bierzo», en Hispania Sacra, 4 (1951) 3-23 y 133-146.

56 Vid. P. FouRACRE, Late Merovigian France: history and hagiography (640-720), London 1996.

57 Á. FÁBrega Grau, I, p. 69. Vid. «Passio beatissimi martyris Felicis, qui passus est sub Datiano preside in civitate Gerunda; die kalendas agustas». Probablemente se mantienen afinidades fraseológi-

Hispania Sacra, LX

121, enero-junio 2008, 9-46, ISSN: 0018-215-X 
Hay, sin embargo, dos circunstancias que aún no se han recogido en esta conclusión y en otros estudios sobre la hagiografía procedente de la «era de las peresecuciones». Primera, ¿por qué en Ávila y hacia la ciudad castellana? Y segunda: ¿se trata de un relato legendario -oral primero, escrito luego- de procedencia popular a partir de una tradición oral, o más bien habría que vislumbrar la intervención de una mano eclesiástica, oficial, por tanto, en la elaboración tardía de una narración que aspiraba a ocultar, sacralizar de acuerdo con los dogmas, recristianizar dentro de la ortodoxia cristiana, una fuerte presencia priscilianista en la posterior ciudad de los santos? Como se puede comprobar, sobre un espacio fundamental, la cripta de la basílica, se mezclarán cultos y tradiciones, espacios funerarios y prácticas litúrgicas relacionadas, fundamentalmente, con tres personajes, Vicente (¿y hermanas?), Prisciliano de Ávila y la Virgen de la Soterraña, uno real e histórico, otro una imagen mariana, siendo el primero un modelo hagiográfico estereotipado, y determinados todos ellos por los avatares históricos de la ciudad y de la propia basílica. Parece así que el movimiento de vulgarización se dirige hacia un conjunto amplio de la población, afectando a las creencias, a las actitudes religiosas, a las modas, a todas las representaciones que sobre la sociedad se hacen los hombres, considerando dos circunstancias radicalmente diferentes. Por una parte, la narración originaria de un suceso martirial sostenida por medio de una tradición sobre san Vicente y sus hermanas, con unos elementos de contraposición a la cultura escrita hegemónica. Por otra, la Iglesia reproduce con variantes el modelo original a partir de unos mecanismos de alfabetización religiosa, es decir, la Passio concreta redactada en el siglo VII, y por medio de productos gráficos, la construcción del cenotafio tardorrománico y todo el aparato iconográfico sobre los mártires a finales del siglo XII. Se busca actuar en un proceso instructivo e ideológico preciso, condicionado por el desarrollo social y económico del mundo medieval.

En cualquier caso parecen superadas las teorías de H. Delehaye y los bolandistas acerca de las leyendas hagiográficas como productos característicos de la cultura popular que se configuran como una operación inconsciente e irreflexiva sobre una historia puntual y concreta, diferenciándose dos elementos, el pueblo, creador anónimo, incapaz de trasladar a la literatura escrita la creación hagiográfica, y el redactor del texto, que trata de codificar una tradición oral mantenida repetitivamente en la memoria colectiva. Al contrario, como apunta R. Manselli, las obras hagiográficas son elaboradas por los miembros más destacados y cultivados del clero ${ }^{58}$.

cas con la Passio Iustis et Pastoris a la hora de crear corpora eorum... honorifice sepelierunt otras tumbas similares para los hermanos, una para Sabina y Cristeta, otra para el varón único.

58 «La vita dei santi, quale viene rappresentata dalla letteratura agiografica di qualsiasi tipo, mentre è rivolta, in gran parte al mondo popolare, è però opera di chierici e non certo dei più incolti», R. MANSELLI, Il soprannaturale e la religione popolare nel Medio Evo, Roma 1985, pp. 35-36. 
Surge la redacción más o menos primeriza de la Passio de Vicente, Sabina y Cristeta cuando la monarquía e Iglesia visigodas centran su actuación contra los restos de arrianismo y desean el sometimiento y control de la población judía. Durante el reinado de Ervigio, Julián de Toledo insiste en contrarrestar los residuos arrianos acerca de la Trinidad, reafirmando doctrinalmente su culto y elaborando la teoría de las tres sustancias para conciliar las naturalezas humana y divina de Cristo, puesta en entredicho un siglo después por la aparición del adopcionismo de Elipando de Toledo y Félix de Urgel. Esa misma reivindicación trinitaria, presente en la Passio (Confitentes Deum Patrem et Filium simulque Spiritum Sanctum..., 9) tiene un mayor alcance religioso cuando el martirio de los tres hermanos se produce en Ávila, una ciudad desorganizada y semiabandonada, conocida por haber sido la sede episcopal de Prisciliano entre los años 380 y 384 .

El intento de erradicar antiguos cultos, viejas supersticiones o lugares sacros se relaciona con la continuidad entre las celebraciones paganas y las festividades de los mártires. En algunas ocasiones, afirma Díaz y Díaz ${ }^{59}$, ciertas disposiciones conciliares desde el siglo $\mathrm{V}$ se esfuerzan denodadamente en suprimir las danzas y representaciones en las fiestas de algunos santos, en lo que habría que ver una supervivencia de hábitos llamados de manera simplificada y disimulada priscilianistas.

En algunas comarcas, tal vez esa protección a Prisciliano no se deba tanto al sostenimiento de una herejía como al mantenimiento de una forma primitiva del cristianismo. En el Cronicón de Idacio ${ }^{60}$ aparece la noticia: Per episcopus quos sibi in eadem prabitate collegerat, Abulae Episcopus ordinatur. Este mismo reconocimiento se presenta en san Jerónimo (De viris illustribus, 121): Priscillianus, Abilae episcopus,... edidit multa opuscula, de quibus ad nos aliqua pervenerunt. La sucesión de concilios reclamando la enérgica desaprobación de unos postulados presuntamente heréticos muestra la extensión y enraizamiento en algunas zonas peninsulares de las expresiones del primer obispo documentado de la diócesis abulense ${ }^{61}$.

La condena de Prisciliano en el concilio de Zaragoza hacía hincapié en la defensa del aparato más ortodoxo del cristianismo, rechazando así una herejía

${ }^{59}$ M. C. DíAz y DíAZ, «Passionnaires...», p. 53.

${ }^{60}$ Vid. Historias de Idacio obispo, que escrivió poco antes qve España se perdiese..., recogidas por don fray Prudencio de Sandoual, obispo de Pamplona, coronista de Su Magestad, Zaragoza 1634, fol. 130. H. FlóREZ, H., España sagrada..., XIV. Apéndice I.

${ }^{61}$ Las actas del Concilio de Toledo, por ejemplo, son recogidas por Chadwick a partir de las transcripciones de Ambrosio de Morales y Juan Bautista Pérez (1537-1597) de un manuscrito (desaparecido) procedente del monasterio de El Escorial: Incipit exemplar professionum habitarum in concilio Toletano contra sectam Priscilliani aera CCCCXXXIII. H. CHADWICK, Prisciliano de Ávila. Ocultismo y poderes carismáticos en la Iglesia primitiva, Madrid 1978, pp. 306-310.

Hispania Sacra, LX

121, enero-junio 2008, 9-46, ISSN: 0018-215-X 
que, según la historia de la Iglesia, era una forma de gnosticismo mezclado con monofisismo y sabelianismo. De manera inmediata, siendo esto lo que interesa, se negaba en el priscilianismo la Trinidad divina, la resurrección y la natividad de Cristo. Paralelamente, aparecía el emanantismo (emanatismo). Por otra parte, sus seguidores consideraban el alma humana como una parte de la naturaleza divina, rechazando el matrimonio y el consumo de carnes, utilizando, por otra parte, libros apócrifos en sus celebraciones. Las diferentes concepciones del alma reflejadas en el movimiento priscilianista actuaron para que los concilios de la época visigoda condenaran irremediablemente la propuesta doctrinal del antiguo obispo abulense, como sucedió en el I Concilio de Toledo (año 397 o 400) o en el I Concilio de Braga (año 561). Así pues, hay que prestar atención al interés, positivo o negativo, que la bibliografía eclesiástica concede al priscilianismo, síntoma probablemente evidente de su extensión a finales del siglo IV y durante las centurias siguientes.

Si Prisciliano y su herejía actuaron como un revulsivo en el culto de los santos en el centro peninsular, si aparentemente no se conocen mártires de la época tardorromana o pasiones referidas al norte del Sistema Central hasta los límites imaginarios de la línea León-Calahorra es porque la diócesis abulense necesitaba ser regenerada en sus actividades, erradicando un culto relacionado con la asimilación profunda de rituales indígenas y fenómenos priscilianistas en un marco social caracterizado quizás por el descontento hacia la jerarquía eclesiástica, posiblemente también situada a medio camino entre la ortodoxia y el desviacionismo religioso. Nada mejor que introducir el culto de los santos Vicente, Sabina y Cristeta para contribuir a la desaparición de las barreras indestructibles entre el cielo y la tierra, entre el futuro homogéneo y los cultos en apariencia indestructibles de la masa campesina ${ }^{62}$, entre una religiosidad popular anclada en un pasado mítico y una mítica heroica centrada en tres hermanos que casual o causalmente llegan a la ciudad de los antiguos vettones, originándose ciertas superposiciones toponímicas y religiosas en lugares muy precisos.

En primer lugar, el culto a los mártires priscilianistas se mantendrá durante varias décadas, al menos hasta la llegada de los musulmanes a la Península y, acaso, con los momentos iniciales de las repoblaciones. Segundo, los restos de Prisciliano y sus discípulos seguirán, en su regreso a la Hispania de finales del siglo IV, la senda que posteriormente se convertirá en la ruta jacobea, la antigua Via Turonensis del occidente francés. Por último, a partir de la cultura mozárabe y, sobre todo, de la repoblación iniciada en el siglo XI, algunos caminos peninsulares se llenan de topónimos y lugares sacros bajo la denominación de San Vicente, el de Ávila en unos casos, el de Zaragoza en otros, o falsos y victoriosos «vicentes», sobre itinerarios precisos que arrancan del Alentejo (Évora), re-

62 P. BRown, The culte of the saints. Its rise and function in latin christianity, Chicago 1981, pp. 9-10. 
corren la provincia castellana de los mártires y concluyen en los alrededores de Compostela para marcar un nuevo rumbo paralelo al Camino de Santiago.

En este sentido, existen más argumentos para suponer que la presencia de rituales priscilianistas durante la etapa visigótica sirvió como excusa y argumento para inventar una leyenda, divulgar una Passio a partir de otras similares, adecuarla a un momento histórico político, la aparición del judío, y eclesiástico, reivindicación trinitaria, e instalarla en el marco preciso de Ávila recogiendo, además, algunas tradiciones, como la cueva y el abandono de los cadáveres en una necrópolis, que provocaran casi inmediatamente un mediana aceptación por parte de los pobladores y, evidentemente, por el clero local.

Esta creación tardía del relato hagiográfico será la causa, por otra parte, de los propios límites del culto de los mártires Vicente, Sabina y Cristeta en la diócesis abulense, de la tímida repercusión topo-hagiográfica de los tres hermanos en otras zonas peninsulares, aunque sean cercanas a la ciudad, y la construcción de un espectacular cenotafio que no tenía otra misión que la de recordar a los ciudadanos de finales del siglo XII el espejismo de una historia santa relativamente reciente.

Vicente, Sabina y Cristeta vivieron y murieron en un martirio a principios del siglo IV. Setenta y cuatro años después es nombrado obispo de Ávila Prisciliano. En ese intervalo nada existe, no se registra ninguna referencia concreta sobre los santos, ni siquiera se menciona un culto en las actas de los mártires recogidas mucho más tarde por los autores altomedievales. Sólo una sepultura, posiblemente de los siglos IV o V, se podría reseñar en un medio físico muy concreto, el de las viejas piedras, lápidas y sepulturas acaso abandonadas de la antigua necrópolis romana. Sin embargo, con el paso de los años, el reducido culto local de los mártires se extenderá, tornándose más complejo a medida que se asienta la monarquía visigoda en relación con la condena del arrianismo, el olvido represivo de la herejía priscilianista, los primeros obispos visigodos de la ciudad y la consolidación eclesiástica de una organización metropolitana.

Al menos ésta era la pretensión episcopal, pero cambiando los sujetos: el limitado culto local al primer obispo Prisciliano se mantuvo precariamente, reduciéndose con el paso del tiempo. La presencia arriana supuso un enganche más y un peligro para los habitantes que aún conservaban las viejas prácticas cristianas procedentes de finales del siglo IV;. En una situación de claro deterioro episcopal, los obispos visigodos de la diócesis abulense no llegan a tomar el control de la ciudad, de ahí su escaso relieve en los concilios visigodos cuando éstos tratan de condenar los rituales priscilianistas y reconvertir el arrianismo a la ortodoxia católica. De ahí que el mundo eclesiástico bajomedieval trate de llenar el vacío dejado en la alta Edad Media incorporando a este último período aquellos personajes que hubieran deseado mostrar en tiempos mejores: la Sote- 
rraña, Paula Barbada, los propios mártires. De ahí también que, una vez instalada la basílica, la preocupación en torno a las reliquias de los hermanos no se recupere más que tardíamente, hasta el último tercio del siglo $\mathrm{XV}$, siendo obispo Martín de Vilches y a partir de la hagiografía barroca del siglo XVII.

En una aparente contradicción, desde el siglo VII, el Pasionario empieza a contar lo que no sucedió. La emergencia de santos y mártires se produce más en el período visigodo que durante las persecuciones de Diocleciano. Al menos fue en ese siglo cuando se recopilan las antiguas tradiciones y se añaden nuevos apartados que, en el caso de Vicente, Sabina y Cristeta, están directamente relacionados con el contexto histórico de la monarquía de los godos. Exceptuando algunos nombres, como Vicente de Zaragoza, Eulalia de Mérida o el obispo y los diáconos de Tarragona, los demás mártires tenían un culto muy reducido. La existencia de algunos individuos santos, que en los pasionarios y legendarios se muestran únicamente como «santos en papel», sirve para constatar parcialmente algunas prácticas religiosas locales a partir de un interés específico por consagrar unas devociones impuestas por una autoridad eclesiástica.

Señala Carmen García Rodríguez que «con excepción de algunos mártires que adquirieron pronto una fama excepcional por circunstancias especiales, de la mayoría de los mártires españoles sólo empezó a difundirse el culto a fines del siglo VI o principios del VII cuando se empezaron a utilizar las reliquias en la consagración de las basílicas. Antes probablemente se limitaba a la ciudad que conservaba sus restos» ${ }^{63}$. Un culto casi desapercibido relacionado con Vicente y sus hermanas se relanzará a partir del siglo VII cuando el arrianismo poco a poco va siendo arrinconado, aunque era necesario aún confirmar literaria y documentalmente el dogma de la divinidad de Jesucristo y el misterio de la Trinidad. De nuevo aparece un intento por erradicar tanto los restos priscilianistas en algunos territorios peninsulares, en la diócesis de Abela, como el deseo de afirmar los errores del arrianismo, es decir, las relaciones asignadas a las tres personas de la Trinidad, negando Arrio la identidad de sustancia del Padre y del Hijo y la categoría divina a Cristo.

Las referencias a este misterio en la narración sobre Vicente, Sabina y Cristeta no pueden ser consideradas unas notas marginales, sino una estrategia para

${ }^{63}$ C. García Rodríguez, 387. Las noticias sobre mártires aportadas por el Peristephanon serían evidentemente residuales, escasamente significativas sobre el desarrollo litúrgico de un santo. Como indica J. Ma . BLÁZqUEZ, «Orígenes del cristianismo hispano», en Historia de España, I, p. 420, «la vida de estos mártires, en tiempos de Prudencio, no era más que un nombre». A pesar de las dificultades metodológicas, es posible reconstruir el nacimiento y desarrollo posterior del relato hagiográfico sobre Vicente, Sabina y Cristeta en la línea marcada, para otros casos, por J. DuBoIs, Les martyrologes du Moyen Âge latin, Turnhout 1978, y J. DuboIs y J.-L. LEMAîTRE, Sources et méthodes de l'hagiographie médiévale, Paris 1993. 
tratar de eliminar esos brotes de los seguidores de Prisciliano y, por otro lado, y para asentar en la diócesis y en general en la monarquía visigoda la victoria de la Trinidad. Priscilianistas, arrianos y judíos, tan diferenciados entre sí, compartían la creencia en una sola divinidad, evitando en la medida de lo posible la figura compleja de la Santísima Trinidad, que podía surgir como una forma más de politeísmo. Esto importa mucho para comprender el desarrollo hagiográfico de los mártires abulenses:

Junto a este proceso, hay que señalar otros acontecimientos significativos que coinciden con la aparición de un Pasionario firmemente redactado y que especificaba la vida y martirio de cada santo. En el 682, un año después de redactarse las ordenanzas litúrgicas por Julián de Toledo, se inaugura la nueva litúrgica hispánica unificada, en la que el aspecto más interesante es la presentación de las actas según un orden cronológico, recogiéndose el título, el nombre del santo, el lugar del martirio o del culto, la fecha de la persecución, el día de la celebración y algunas ampliaciones martiriológicas, unificándose los antiguos textos de libelli orationum de Toledo y ordenando las diversas lecturas hagiográficas.

Esta aceleración en la creación de pasiones concretas se relaciona también con la prohibición expresada por los concilios toledanos del siglo VII (canon 2, IV Concilio) sobre el cántico de himnos en las celebraciones de los tiempos litúrgicos y festividades de santos, rituales que estaban identificados de manera expresa con algunas costumbres priscilianistas. Con los textos hagiográficos de Fructuoso y sus diáconos, Vicente de Zaragoza, Saturnino de Toulouse, Esteban y Eulalia de Mérida, añadiéndose la Passio de santa Colomba de Sens, se redactarían aquellas pasiones locales vinculadas con devociones también locales (Justo y Pastor, Cucufate, Leocadia de Toledo, Justa y Rufina de Sevilla, Vicente y hermanas). A partir de la Passio sancti Vincentii, Sabinae et Christetae... Unas décadas más tarde, en la segunda mitad del siglo VIII, se desarrollaría la missa de los mártires abulenses, a la vez que su culto pasaría, a comienzos del siglo $X$, a la liturgia general española.

Institucionalizado así el culto, habrá que esperar a la repoblación de finales del siglo XI para que todo el conjunto de tradiciones y leyendas, personajes concretos y misterios teológicos, persecuciones y relaciones interpersonales se plasmen en las imágenes de la basílica. Única forma de difundir una liturgia ya oficial en el nuevo marco de Ávila desde la «hagiocracia» surgida en la etapa visigoda. Esta noción, en la línea marcada por André Vauchez ${ }^{64}$ se entiende como la aparición de santos estrechamente asociados con el poder político en el período que va desde finales del siglo VI a finales del VIII y que alcanzó una plena legitimación religiosa en tiempos posteriores.

${ }^{64}$ A. VAUCHEZ, «El santo», en J. LE GofF (ed.), El hombre medieval, Madrid 1990, pp. 332-333.

Hispania Sacra, LX

121, enero-junio 2008, 9-46, ISSN: 0018-215-X 
El triunfo del mártir sobre la vida temporal se manifiesta en las denominaciones que recibe, victor, victrix, triumphator en un sentido litúrgico, desde el momento en que los hermanos Vicente, Sabina y Cristeta conquistan la gloria por su laudabili morte: Hic [Vincentius] etiam suis cum sororibus hodie laudabili consumptus est morte: hodie partiter ineffabili sunt reminerati mercede (Liber Mozarabicus Sacramentorum, 1096: 503, 1). En los discursos hagiográficos se presentan necesariamente los aspectos épicos, aquellos que resaltan una victoria del mártir ante la nula resistencia,--como mucho hay una resistencia locuaz, que previamente ha presentado frente a sus perseguidores y torturadores. Jesús Camarero ha señalado cómo, en este contexto martirial, la muerte se ofrece como ganancia, una «actitud escatológica que menospreciaba incluso la muerte y se ancla en el paso triunfal a la gloria definitiva» 65 , insistiendo en el carácter pascual a partir de una forma literaria formada por cláusulas antitéticas:

Fuerit hic licet corporalis punitio per supplicium, est tamen victoria per triumphum. Sit quamvis mors inlata supplicio, sed vita felix manet in regno. -Non enim punivit crudelitas quos cupit, quos in se Trinitas victores effecit. Punivit quidem ut potuit: non punivit ut voluit. Inmanis quippe ferocitas sanctorum voluntati nolendo deserviens, membra tantum punit suppliciis, animas suo expiatas vulnere transmitiit in celis. / Quosque hic ne vincerent timuit, hos post mortem victores intellexit: quum illorum corporibus previdit celitus impendi honorem, quibus ipse rabidus intulerat necem.

(Liber Mozarabicus Sacramentorum, 1097: 22 ss.)

Así pues, el relato martirial sobre Vicente, Sabina y Cristeta alterna entre la descripción realista del proceso judicial, cuando el praeses procede al interrogatorio del prisionero Vicente, y la sucesión de la ejecución de los hermanos con la aparición del judío y la serpiente, soslayando la figura del obispo Prisciliano, imágenes literarias que servirán para acentuar tanto la muerte física como el óbito en un sentido más teológico, pues lo característico del mártir es el tránsito dirigido por la divinidad hacia la plenitud escatológica, un aspecto que ha sido resumido en la plasmación de las virtudes teologales en relación con la dinámica pascual: Fides pervenit ad fructum, spes ad premium, charitas ad regnum, passio ad triumphum (Liber Mozarabicus Sacramentorum, 1096: 25 ss.).

La dificultad de reconstruir exactamente las fases de redacción de la leyenda sobre los mártires abulenses procede de las incertidumbres cronológicas, al igual que resulta complicado seguir su reinterpretación y su difusión en algunos territorios peninsulares, Ávila, Burgos, Évora, Toledo y El Bierzo, sobre todo. Para Ávila, tal vez el clero ligado a la basílica, en el siglo XII, extrapoló aquellos elementos narrativos o discursivos, útiles tantopara su aceptación popular y para su plasmación en las imágenes del cenotafio tardorrománico. La identificación de al-

65 J. CAMARERo CuÑAdo, La figura del santo..., pp. 339 y 342. 
gunos pasajes de la narración hagiográfica conduce a confrontar estas varias lecturas en la diversidad de sus concepciones y en su plasmación ideológica.

Por ejemplo, en el primer relato hagiográfico del siglo VII, ligado a la Passio de santa Leocadia, se observa una especie de concepción ascética de la exégesis, limitándose a constatar unos acontecimientos pretéritos, legendarios y con un fin litúrgico, mientras que a partir de una reelaboración de la Passio de los tres hermanos se sostiene implícitamente una visión militante de la cultura eclesiástica y de la tradición hagiográfica, relacionada con las exigencias pastorales del momento y con las aspiraciones políticas de la monarquía visigoda. Más tarde, en la lectura iconográfica del cenotafio de la basílica de San Vicente, esta reinterpretación estará desprovista de cualquier referencia concreta al mundo tardorromano para convertirse en un vehículo consciente de la predicación. Estrechamente ligada así con el siglo VII, la segunda redacción de la leyenda aparece con una inserción característica, la tipología del judío definido con cierto rigor e imaginaria uniformidad, coincidiendo con los deseos políticos y eclesiásticos de la monarquía visigoda. Se modifica profundamente el relato inicial al despreciar tanto el diálogo del mártir Vicencio con el pretor como la lenta huida de los hermanos a Ávila. Por otra parte, de un único martirio se pasará a un doble proceso mortal, el de los esbirros romanos (medievales en el cenotafio) y el de un judío no tan curioso. Las implicaciones teológicas perderán fuerza ante la escabrosa imagen del hebreo atrapado por la serpiente. La posibilidad de operar este cambio de una redacción a otra se debe, fundamentalmente, a la utilización de la metáfora como una estrategia retórica de tipo propagandístico: la descripción realista convive con una intención moralizante. El sistema de representación de la realidad imaginaria insistía en resaltar los aspectos más sobresalientes de la tradición cristiana, como la fe, la gloria, el poder divino, y de unos modelos idealizados procedentes de diversos ámbitos: el judío, la serpiente, los milites.

En resumen, con la invención y difusión de la Passio de Vicente, Sabina y Cristeta se pretendía romper con el pasado y el presente cotidiano impregnado de contaminaciones priscilianistas, reagrupando a los fieles abulenses en torno a una nueva creencia fundamental, extendiéndose paulatinamente a los grupos sociales existentes y planteando abiertamente una lucha contra las autoridades eclesiásticas que todavía avalaban las primeras creencias. Más tarde, levantada ya la basílica, se procederá a una más precisa elaboración iconográfica y conceptual, acentuándose el misterio del judío que, por medio de una promesa ideológica, levanta la primera tumba. Un curioso hebreo del siglo IV que, tras vislumbrar su fatal desenlace por el abrazo mortal de una gran serpiente, se arrepiente de su intervención en el martirio de los santos, reniega de su pasado y promete construir sobre un berrocal tres sepulcros, uno para cada hermano, sobre el lugar en que se levantará unos siglos después la espectacular basílica románica. 